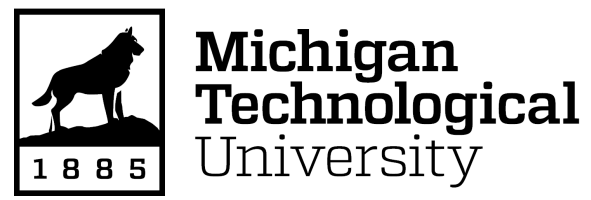

Michigan Technological University Digital Commons @ Michigan Tech

Dissertations, Master's Theses and Master's Reports

2021

Structural Analysis and Interpretation of Deformation Along the Keweenaw Fault System West of Lake Gratiot, Keweenaw County, Michigan

Sophie A. Mueller

Michigan Technological University, sophiemu@mtu.edu

Copyright 2021 Sophie A. Mueller

Recommended Citation

Mueller, Sophie A., "Structural Analysis and Interpretation of Deformation Along the Keweenaw Fault System West of Lake Gratiot, Keweenaw County, Michigan", Open Access Master's Thesis, Michigan Technological University, 2021.

https://doi.org/10.37099/mtu.dc.etdr/1167

Follow this and additional works at: https://digitalcommons.mtu.edu/etdr

Part of the Geology Commons, and the Tectonics and Structure Commons 


\title{
STRUCTURAL ANALYSIS AND INTERPRETATION OF DEFORMATION ALONG THE KEWEENAW FAULT SYSTEM WEST OF LAKE GRATIOT, KEWEENAW COUNTY, MICHIGAN
}

\author{
By
}

Sophie A. Mueller

\begin{abstract}
A THESIS
Submitted in partial fulfillment of the requirements for the degree of

MASTER OF SCIENCE

In Geology

MICHIGAN TECHNOLOGICAL UNIVERSITY

2021
\end{abstract}

(C) 2021 Sophie A. Mueller 
This thesis has been approved in partial fulfillment of the requirements for the Degree of MASTER OF SCIENCE in Geology.

Department of Geological and Mining Engineering and Sciences

\author{
Thesis Co-Advisor: $\quad$ James M. DeGraff \\ Thesis Co-Advisor: $\quad$ Chad Deering \\ Committee Member: Jeremy Shannon
}

Department Chair: Aleksey Smirnov 


\section{Table of Contents}

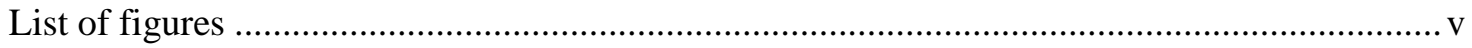

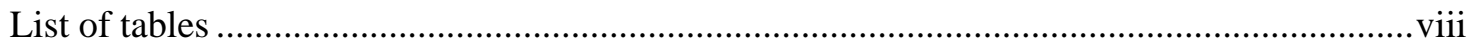

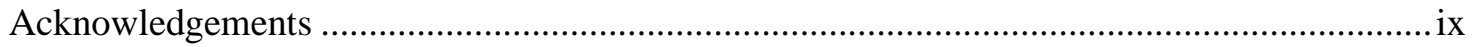

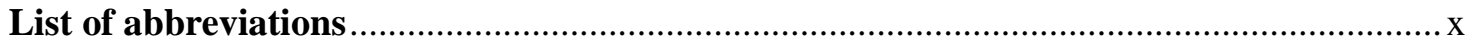

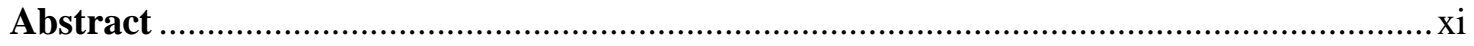

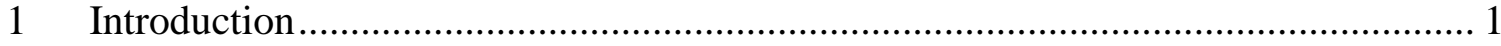

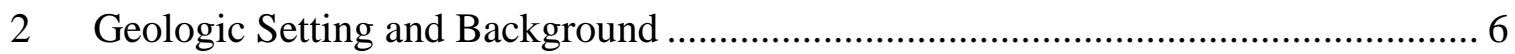

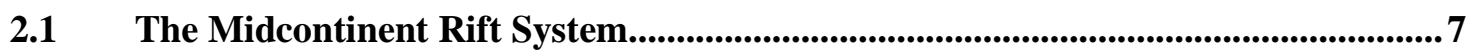

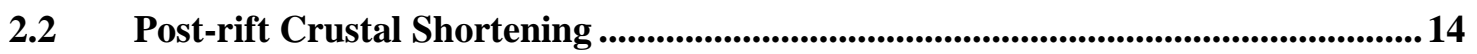

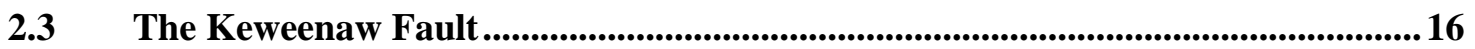

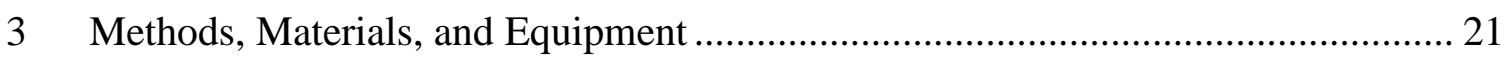

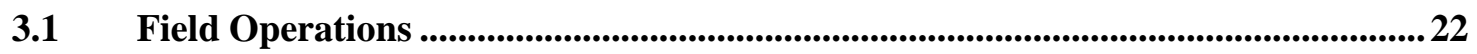

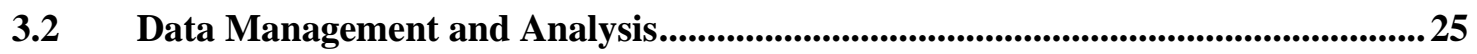

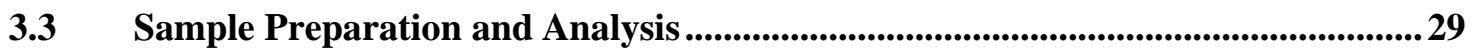

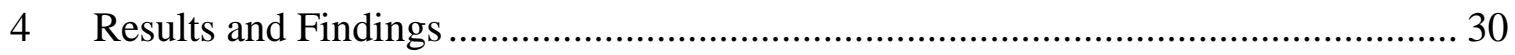

4.1 EdMap Project Area: Summary of Fault and Fold Patterns ......................................33

4.2 Focus Area West of Lake Gratiot: Map Changes and Structural Geometries..... 35

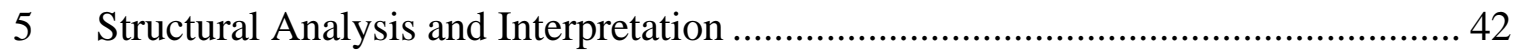

5.1 Bruneau Creek Transect..........................................................................................................42

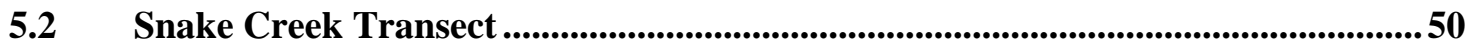

5.3 Fault Slip Characteristics and Kinematic Analysis ................................................55 


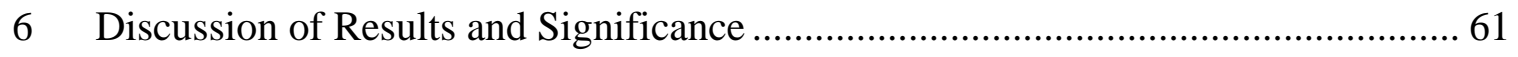

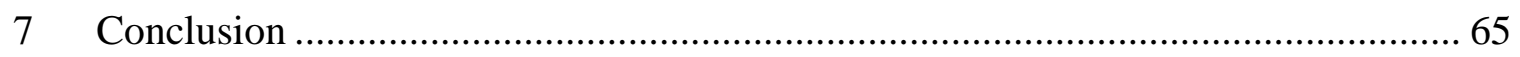

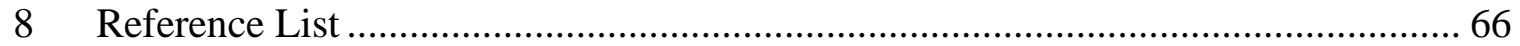




\section{List of figures}

Figure 1: Keweenawan geology of the Midcontinent Rift System in the Lake Superior Basin (Miller and Nicholson, 2013). Credit: Precambrian Research Center Guidebook 13-01, p.5.

Figure 2: Cross sectional view of the Keweenaw Peninsula .3

Figure 3: Geologic map of the Keweenaw Peninsula with EdMap Project areas outlined, adapted from Geologic map of the Keweenaw Peninsula and adjacent area, Michigan (Cannon and Nicholson, 2001) ......................................................

Figure 4: Map showing extent of the Midcontinent Rift System and position of the Grenville Front (Stein et. al., 2011; Huber, 1973)...............................................

Figure 5: Timeline of stages associated with MRS evolution. Three stages of magmatic activity (Plateau, Rift, and Late-Rift states) are shown, followed by an extended period of clastic sedimentation and a subsequent compressional event (Post-Rift and Compressional Stages). Estimated time intervals for magnetic polarity are also shown as ' $\mathrm{R}$ ' and ' $\mathrm{N}$ ' for reversed magnetic polarity and normal magnetic polarity, respectively (Woodruff et al., 2020).

Figure 6: Stratigraphic column of the Western Upper Peninsula, Michigan, adapted from Kulakov, 2013. Radiometric ages are shown, along with ' $R$ ' and ' $N$ ' representing times of reversed and normal polarity (Davis and Paces, 1990) .10

Figure 7: Main textural varieties of basalt observed in the study area. Left to Right: Massive, Ophitic, Amygdaloidal. Source: Keweenaw Geoheritage \& Michigan Technological University. .11

Figure 8: Timeline of the Midcontinent Rift System in relation to the Grenville Orogeny and other key geologic events. JBE represents the Jacobsville Sandstone, Bayfield Group, and other equivalent sedimentary rocks which overlie the volcanics and sediments deposited in the MCR basin (Malone et al., 2016). .15

Figure 9: Workflow for geologic data transcription, organization, and analysis..............26

Figure 10: Workflow for geospatial data importation and visualization in ArcMap........27

Figure 11: Compiled 7.5-minute bedrock geology quadrangles of Cornwall (1954), Cornwall and Wright (1954), Davidson et al. (1955), and Wright and Cornwall (1954). EdMap project area is outlined by a black perimeter; areas of mapping responsibility are indicated by initials DJLM (Lizzadro-McPherson) and SAM (Mueller). Portage Lake Volcanics with green tones occur northwest of the Keweenaw fault in the hanging wall; Jacobsville Sandstone in light orange to pink tones occurs southeast of the fault in the footwall. 
Figure 12: Updated bedrock geology map of the EdMap project area. Map legend here applies to subsequent detailed maps of focus areas (red letters). Opposing arrows indicate sense of strike slip on faults; letters " $U$ " and "D" denote relative upward and downward dip slip.

Figure 13: EdMap project geology map with MS thesis focus area outlined and enlarged in inset.

Figure 14: A. Published USGS bedrock geology map for Area 1 near where Bruneau and Snake creeks cut across the PLV-JS contact (Wright and Cornwall, 1954) B. New bedrock geology map showing multiple fault segments and outcrop data points as black dots. Opposing arrows indicate sense of strike slip on faults; letters " $U$ " and " $D$ " denote relative upward and downward dip slip. Red flower shapes refer to diamond drillhole locations.....

Figure 15: Picture of fault excavated at Bruneau Creek. .39

Figure 16: A: Published USGS bedrock geology map for area 2 near Snake Creek (Wright and Cornwall, 1954). B. New bedrock geology map showing different fault segments and outcrop data points as black dots. Opposing arrows indicate sense of strike slip on faults; letters " $U$ " and "D" denote relative upward and downward dip slip.

Figure 17: Equal-area stereonet plot and analysis of PLV stratal orientations; $N=6$, located west of the PLV-JS contact at Bruneau Creek. Two subsets are defined: group 1 (pink) and group 2 (yellow). Black arc is a best-fit line to bedding poles.

Figure 18: Equal-area stereonet plot and initial analysis of JS stratal orientations at Bruneau Creek east of the PLV-JS contact. Group 1 (black; N=21) is dominant and considered characteristic of first-order folding. Group 2 (pink; $\mathrm{N}=3$ ) is secondorder and considered to represent minor local folding. Group 3 (yellow) is a single outlier excluded from further analysis....

Figure 19: Equal-area stereonet analysis of Group $1(\mathrm{~N}=21)$ JS stratal orientations at Bruneau Creek, representing a composite fold analysis. This dominant group is considered characteristic of first-order folding...... .46

Figure 20: Equal-area stereonet plot analysis of Group $2(\mathrm{~N}=3)$ JS stratal orientations at Bruneau Creek. These values are from adjacent field sites and represent a secondary fold

Figure 21: Geologic cross-section at Bruneau Creek drawn normal to the main Set 3 fault trend in the area. Regional dip in this area is $10^{\circ}$ away from the viewer. Vertical ticks on topographic surface represent individual station numbers. Fold axial surface is drawn to represent apparent dip. 
Figure 22: Equal-area stereonet plot of site-averaged PLV bedding data in the fault hanging-wall along the east branch of Snake Creek $(\mathrm{N}=5)$..................................51

Figure 23: Equal-area stereonet plot of site-averaged JS bedding orientations along Snake Creek tributary and adjacent areas (left); bedding orientations excluding group 2 data from an adjacent drainage to the northwest (right). Group 1 data were used to calculate FW fold geometry at Snake Creek tributary.

Figure 24: Geologic cross-section along the east branch of Snake Creek. Vertical ticks on topographic surface are field site locations. Fold axes are drawn to reflect apparent dip. Stratal dip at the NNW end of the cross section is adapted from the USGS map of the area. .54

Figure 25: Lineations formed parallel to the slip vector (Burg 2020). .55

Figure 26: Asymmetric step formation on a fault surface and relationship to slip sense (Allison 2020). .56

Figure 27: Rake and plunge of lineations on a planar surface (Burg, 2020). .56

Figure 28: Radial histogram of fault lineation rakes counted in $10^{\circ}$ bins. Black arrow denotes arithmetic mean of data. $25 \%$ of data resides within the largest slice. Strikeslip corresponds to rake $=0^{\circ}$; dip-slip corresponds to rake $=90^{\circ}$. Red dots on perimeter are rake values that were counted within bins. .58

Figure 29: Linked Bingham, fault-plane-solution plot showing fault planes (arcs) and lineations (black dots on arcs), using sense of slip to compute principal strain axes. The principal shortening direction is along a line with azimuth $105^{\circ}-285^{\circ}$ (FaultKin from Allmendinger, 2019).

Figure 30: Radial histograms of fault lineation rakes A. 2017-2018 EdMap results $(\mathrm{N}=30)$ B. 2019-2020 EdMap results for western part $(\mathrm{N}=55)$.

Figure 31: FaultKin plots of the first EdMap project (left) and second EdMap project (right) using fault planes, rake lineations, and sense of slip to compute three principal axes of strain. .63 


\section{List of tables}

Table 1: Data Recorded in Field Book ........................................................................24 


\section{Acknowledgements}

I would like to thank my advisor Jim DeGraff for his guidance and support throughout the preparation, execution, and analysis of this research project. I would like to thank my coadvisor, Chad Deering, for his assistance and instruction in mineralogy and petrology. I would like to thank Daniel Lizzadro-McPherson for his hard work and contributions throughout the project. Daniel was largely responsible for map preparation and ArcGIS work. I would like to thank Robert Barron for assistance with samples within the lab and thin section preparation. I would like to thank Jeremy Shannon for his support as a committee member for this project. I would like to thank Gabriel Ahrendt, Ian Gannon, and Ginny Hemmila, our field assistants, for their help during fieldwork and with sample preparation in the lab. I would like to thank the U.S. Geological Survey for EdMap funding and the department of Geologic and Mining Engineering and Sciences at Michigan Technological University for matched financial support. I would like to thank the Michigan Space Grant Consortium for additional funding for this project. Lastly, I would like to thank my parents for their constant encouragement and support throughout my education and this process. 


\section{List of abbreviations}

$\begin{array}{ll}\text { DGPS } & \text { Differential Global Positioning System } \\ \text { EdMap } & \text { Educational Mapping Program (U.S. Geological Survey) } \\ \text { FW } & \text { Footwall } \\ \text { Ga } & \text { Billion Years } \\ \text { GMES } & \text { Department of Geological and Mining Engineering and Sciences, } \\ & \text { Michigan Technological University } \\ \text { HW } & \text { Hanging wall } \\ \text { JS } & \text { Jacobsville Sandstone } \\ \text { KF } & \text { Keweenaw Fault } \\ \text { Ma } & \text { Million years } \\ \text { MRS } & \text { Midcontinent Rift System } \\ \text { P/A } & \text { Plunge and Azimuth } \\ \text { PLV } & \text { Portage Lake Volcanics } \\ \text { S/D } & \text { Strike and Dip } \\ \text { USGS } & \text { United States Geological Survey }\end{array}$




\section{Abstract}

The Keweenaw fault is perhaps the most significant fault associated with the Midcontinent Rift System of the north-central United States. The fault, parallel to the south edge of the rift, has been interpreted as a rift-bounding normal fault that was inverted by subsequent compressional events, thrusting copper-bearing Portage Lake Volcanics $(\sim 1.1 \mathrm{Ga})$ over younger Jacobsville Sandstone. Geologic maps and cross sections published in the 1950s by the U. S. Geological Survey depict the fault with a well-defined, single, sinuous trace that is locally associated with smaller branch faults. Cross-sections from that time generally show a simple listric stratal geometry for hanging-wall lava flows and variable dip of footwall siliciclastic layers, but with little to no fold definition.

New field mapping between Mohawk (MI) and Bête Gris Bay indicates that the Keweenaw fault here is better characterized as a fault system consisting of: 1) segments striking eastnortheast with steep northerly dip, 2) segments striking east-southeast also with steep northerly dip, and 3) segments striking north-northeast with moderate-to-shallow westerly dip. The members of these three fault sets define a multistranded Keweenaw fault system and several large fault-bounded blocks of Portage Lake Volcanics. Mapping also revealed folding in hanging-wall Portage Lake Volcanics and has defined fold geometry in footwall Jacobsville Sandstone. Fold axes are generally subparallel to adjacent faults and therefore are probably related to fault movement. Along Bruneau Creek, multiple anticlines and synclines in the footwall of a Set 3 fault and a faulted anticline in the hanging-wall indicate significant shortening across a west-dipping thrust fault. Along the east tributary of Snake Creek, a single syncline in the footwall of a Set 2 fault resulted from tilting of Jacobsville 
strata to vertical by north-side-up movement of a steeply dipping, right-lateral, strike-slip fault, with minor shortening across the fault.

The pattern and relationships of faults and folds in the area are consistent with a fault system dominated by dextral shear rather than by reverse movement as in the currently accepted model. Kinematic slip indicators measured on 55 small faults demonstrate mostly right-lateral strike slip and lesser north-side-up reverse slip, with a 2.5:1 ratio of strike-todip slip. Inversion of fault-slip data shows that maximum shortening during faulting was along an azimuth of $285^{\circ}-105^{\circ}$, suggesting a WNW-ESE maximum paleostress direction that is nearly parallel to expected Grenville or Appalachian orogenic forces.

The new mapping and structural analyses in this area have revealed a multistranded Keweenaw fault system that is transpressional in nature, dominated by dextral strike slip, and has lesser reverse slip with north side up. Fault-bounded blocks having ENE-oriented long dimensions generally moved eastward along set 1 and 2 faults, while thrusting Portage Lake Volcanics over Jacobsville Sandstone along set 3 faults. The estimated WNW-ESE maximum shortening direction associated with fault movement strongly suggests that the Grenville Orogeny was primarily responsible for movement of the Keweenaw fault system, with possible reactivation occurring during the Appalachian Orogeny. 


\section{Introduction}

The Keweenaw fault in the western Upper Peninsula of Michigan is one of the most significant features associated with the Midcontinent Rift System (Fig. 1). Reverse movement of the fault has thrust older Portage Lake Volcanics (PLV) in the hanging wall over younger Jacobsville Sandstone (JS) in the footwall (Cannon and Nicholson, 2001). The fault features a $\sim 250 \mathrm{~km}$ trace and $\sim 9 \mathrm{~km}$ of postulated slip near Houghton, Michigan (DeGraff et. al., 2018), and is one of several major reverse faults that roughly parallel the rift along its inferred margins (Miller and Nicholson, 2013).

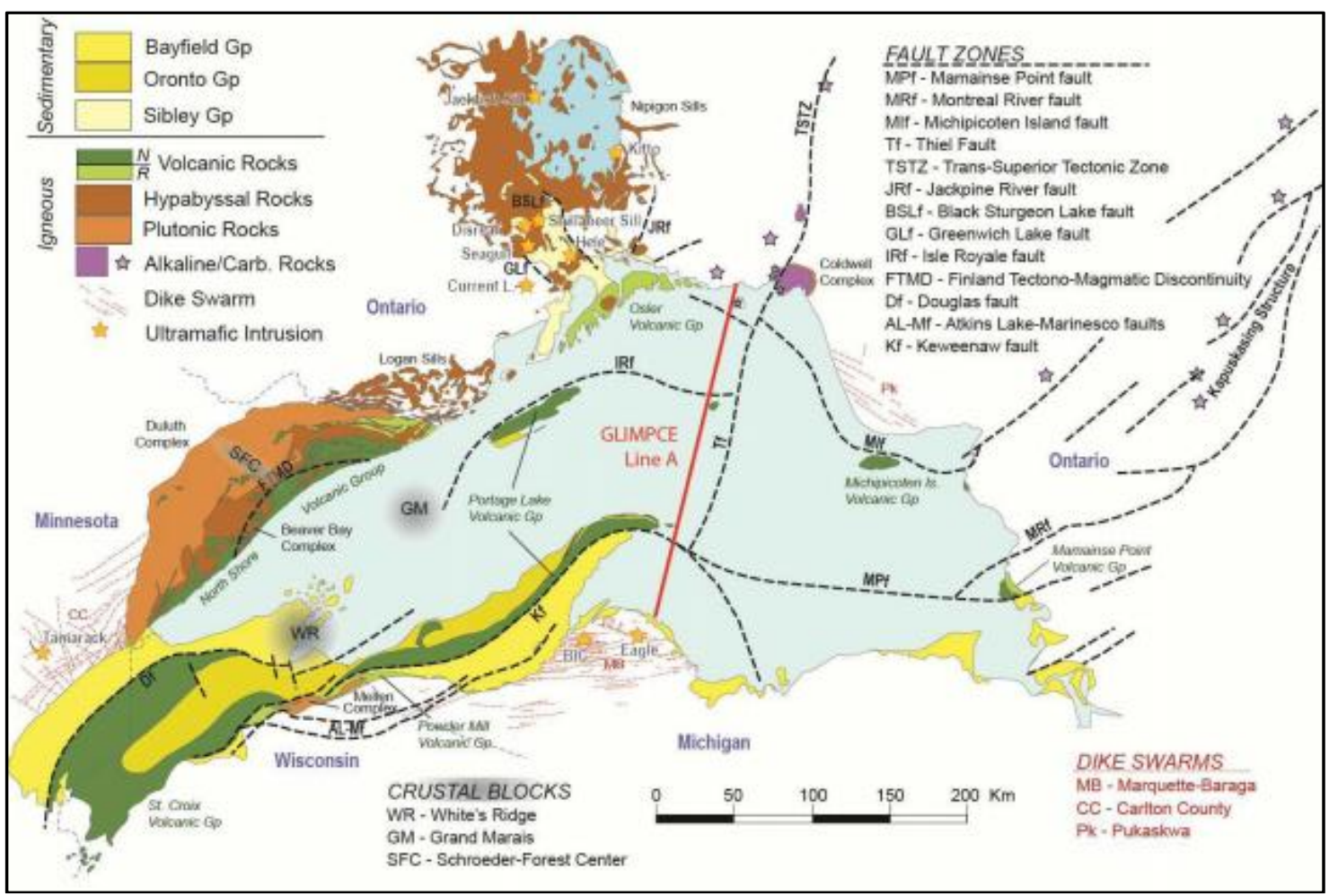

Figure 1: Keweenawan geology of the Midcontinent Rift System in the Lake Superior Basin (Miller and Nicholson, 2013). Credit: Precambrian Research Center Guidebook 13-01, p.5. 
Once economic copper deposits in the region motivated mapping and studies of the Keweenaw fault since the mid-1800s, which generated much debate about its nature and timing of slip. Early geologists considered the Keweenaw fault to be a simple reverse fault that originated after eruption of vast amounts of lava and deposition of clastic sediment during basin subsidence (Irving and Chamberlin,1885; Butler and Burbank, 1929). When an ancient rift system known as the Midcontinent Rift System (MRS) was recognized around 1970, a general consensus developed that the Keweenaw fault originated as a normal fault during rifting and then was reactivated as a reverse fault by crustal shortening during the Grenville Orogeny (Gordon and Hempton, 1986). Thus, the commonly accepted interpretation is that the Keweenaw fault is an inverted normal fault (Cannon, 1994; Hnat et al., 2006).

United States Geological Survey (USGS) bedrock geology maps published in the 1950s show the Keweenaw fault as a single, sinuous trace with associated smaller faults and splays. These maps, based in part on mining and aeromagnetic data, provide a good geological framework and variable resolution of the fault trace. However, they do not incorporate modern positional technology, geospatial mapping capabilities, or understanding of fault kinematics, all of which have advanced significantly since the 1950s. Cross-sections on the published maps depict a relatively simple structural scenario, featuring homoclinal dip in the hanging wall that decreases northwest towards Lake Superior (Fig. 2). Some cross-sections show local deformation in the hanging wall, including secondary fault splays and local folding near the fault contact. However, fault- 
slip indicators have not been measured, fold geometries have not been adequately described, and no detailed structural analysis has been performed in this region.

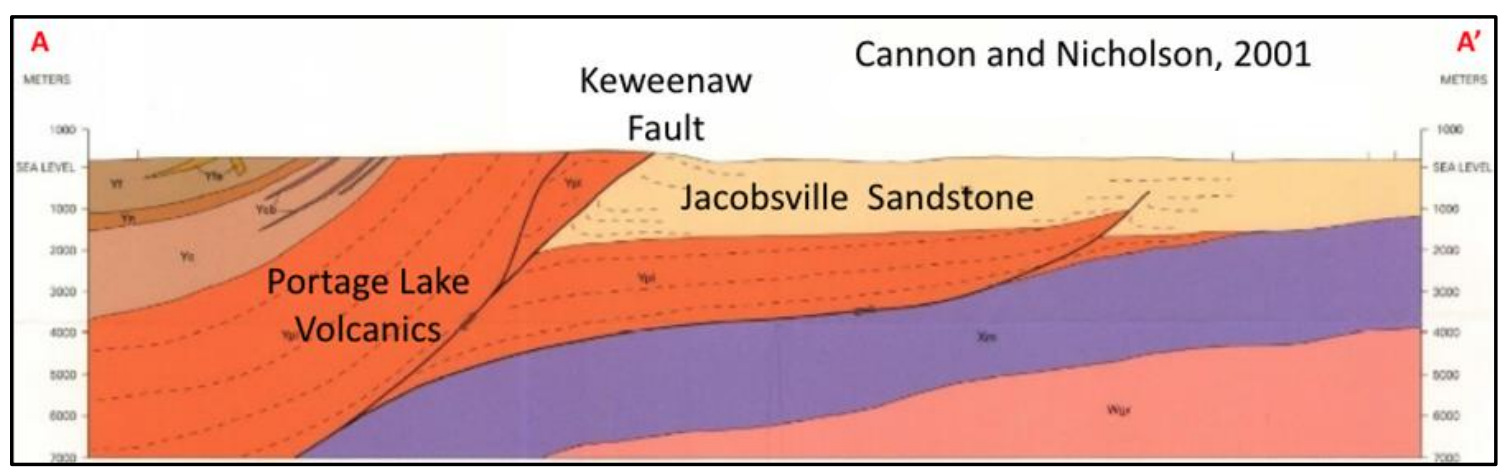

Figure 2: Cross sectional view of the Keweenaw Peninsula

Recent mapping conducted as part of the 2017-2018 USGS Educational Mapping Program (EdMap) has revealed new details about the Keweenaw fault between Bête Grise Bay and the tip of the Keweenaw Peninsula (Fig. 3; DeGraff, et al., 2018; Tyrrell, 2019). The mapping showed that the Keweenaw fault here is not a single, sinuous fault; rather, it is better characterized as a fault system consisting of ESE-oriented, left-stepping en echelon faults connected by ENE-trending faults. Additionally, fault slip indicators in this area show overall fault movement to have a 2:1 ratio of strike slip to dip slip. These results have implications for fault kinematics, related folding, and regional stresses that likely apply to other segments of the Keweenaw fault. These implications can be quantitatively evaluated elsewhere along the Keweenaw fault system to better understand fault kinematics and deformation geometry. 


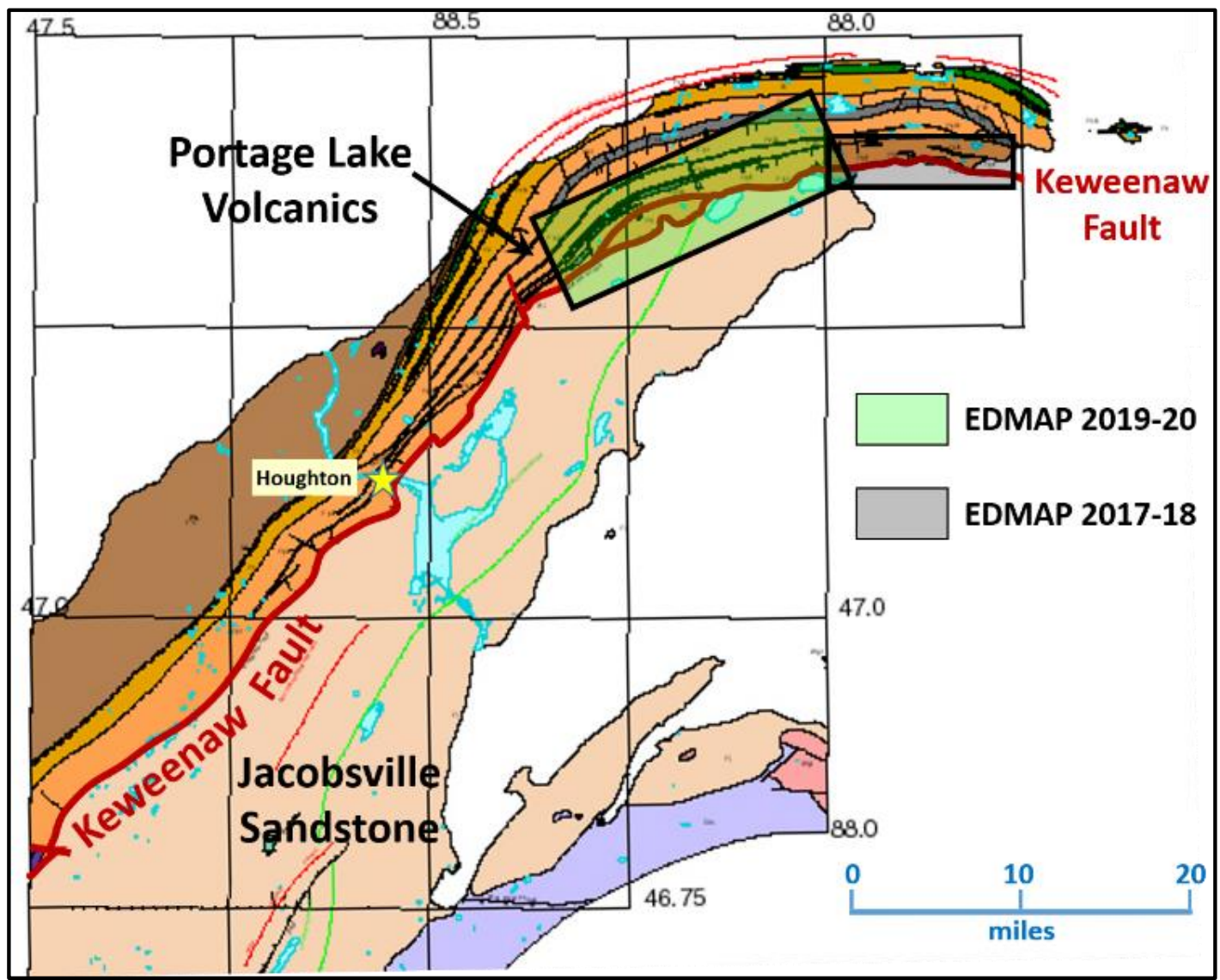

Figure 3: Geologic map of the Keweenaw Peninsula with EdMap Project areas outlined, adapted from Geologic map of the Keweenaw Peninsula and adjacent area, Michigan (Cannon and Nicholson, 2001).

A second EdMap project in 2019-2020 focused on the Keweenaw fault between Mohawk, Michigan and Bête Grise Bay in order to extend the mapping of the first project and to test whether the earlier findings would apply to the adjacent area. The second project provides further information about fault geometry, slip kinematics, and fold geometry, and forms the basis for this thesis project. Utilizing modern technology and contemporary understanding of fault systems, this thesis project aims to establish an updated and more comprehensive understanding of Keweenaw fault kinematics and related deformation geometry. A robust bedding orientation dataset shows evidence of folding in both the 
hanging-wall and footwall of the fault and is analyzed to define fold geometry in relation to nearby faults. Abundant measurements of fault-slip indicators are analyzed to better define fault kinematics and overall slip direction in this region. Together, results from these investigations are used to explore relationships between fold geometry and fault slip direction. The outcome of this study ultimately provides a better understanding of the overall shortening direction across the Keweenaw fault, and provides insight as to the tectonic setting that drove fault slip. 


\section{Geologic Setting and Background}

The Keweenaw Peninsula is centrally located along the southern shore of Lake Superior and along the southern margin of the Midcontinent Rift System (MRS, Figs. 1 and 4). The geology of the peninsula is a product of lava extrusion and sediment deposition during rifting and subsequent basin subsidence, followed by reverse faulting during one or more compressional tectonic events. The Keweenaw fault roughly bisects the peninsula and juxtaposes Mesoproterozoic volcanic rocks in the hanging-wall against Meso- to Neoproterozoic sedimentary strata in the footwall. The origin and nature of the Keweenaw fault have been much debated, but a general consensus has emerged that the fault began as a rift-bounding normal fault and later was reactivated as a reverse fault by a post-rift compressional event. The importance of rifting and subsequent crustal shortening to the geology of the Keweenaw Peninsula requires some discussion of the MRS and post-rift orogenic events. 


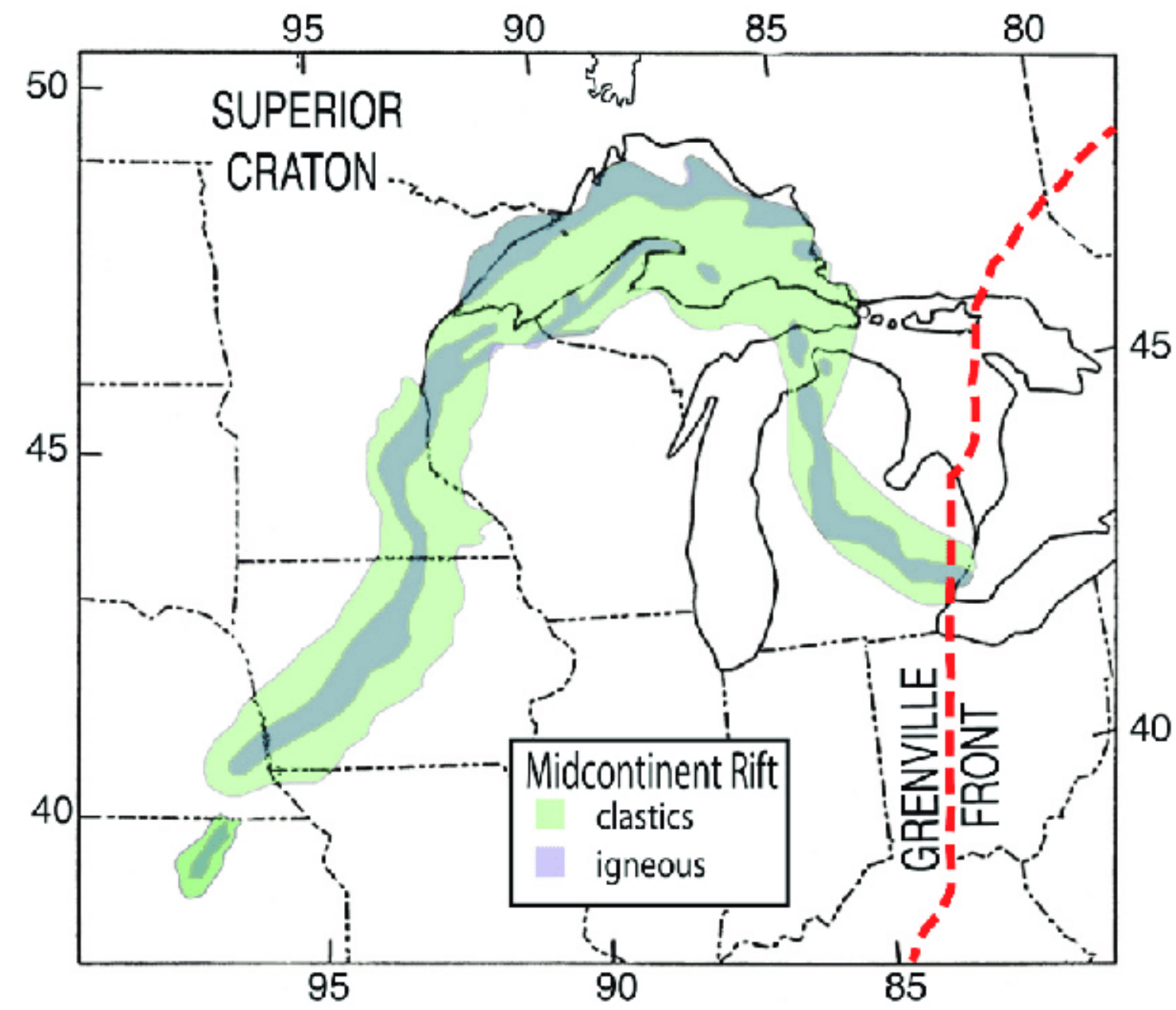

Figure 4: Map showing extent of the Midcontinent Rift System and position of the Grenville Front (Stein et. al., 2011; Huber, 1973).

\subsection{The Midcontinent Rift System}

The Mesoproterozoic Midcontinent Rift System (MRS) formed by extension and rupture of the North American plate (Laurentia craton) approximately 1.1 Ga ago (Hutchinson et al., 1990). Numerous investigations since the 1970s have led to general agreement on the phases of rifting, though some of the details are still debated. The rift phases are: 1) widespread extension and volcanism; 2) localized rifting and volcanism; 3) subsidence 
with continued volcanism; and 4) subsidence with sedimentation (Fig. 5). Later, compressional forces probably related to orogenesis modified the rift system and caused reverse slip on major faults around the Lake Superior basin (Fig. 1).

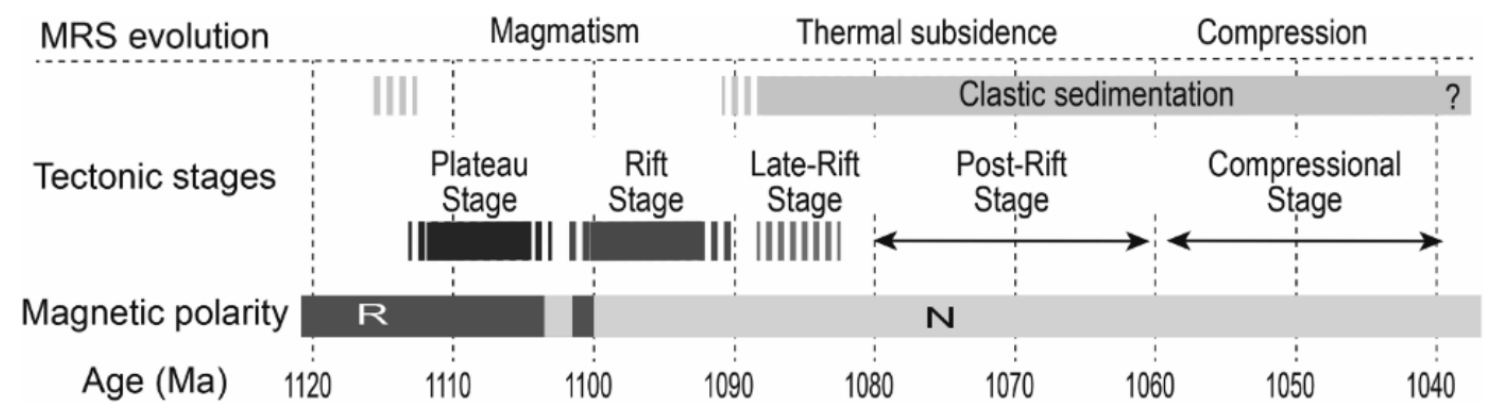

Figure 5: Timeline of stages associated with MRS evolution. Three stages of magmatic activity (Plateau, Rift, and Late-Rift states) are shown, followed by an extended period of clastic sedimentation and a subsequent compressional event (Post-Rift and Compressional Stages). Estimated time intervals for magnetic polarity are also shown as ' $\mathrm{R}$ ' and ' $\mathrm{N}$ ' for reversed magnetic polarity and normal magnetic polarity, respectively (Woodruff et al., 2020).

The first phase of rifting, associated with broad uplift and widely distributed volcanism, transitioned into a second phase as extension became localized into narrow subsiding rift basins. The first phase is extensional and can be subdivided into three magmatic stages based on age, physical volcanology, magnetic polarity, and geochemistry: 1. Plateau Stage ( 1112 to $\sim 1105 \mathrm{Ma}), 2$. Rift Stage $(\sim 1102$ to $\sim 1090 \mathrm{Ma})$, and 3. Late-Rift Stage $(\sim 1090$ to $1083 \mathrm{Ma}$ ) (Fig. 5; Woodruff et al., 2020). During the broad extensional phase, large volumes of mafic magma and smaller volumes of felsic magma erupted over Archean and Paleoproterozoic crust. These successive eruptions are thought to be sourced from a mantle plume underlying the passive rift (Hutchinson et al., 1990; Nicholson and Shirey, 1990). 
Early eruptions in the Plateau Stage during the Middle Proterozoic led to formation of the Powder Mill Group, which has reversely polarized remanent magnetization (Davis and Paces, 1990; Woodruff et al., 2020). The Bergland Group, which includes the PLV and younger formations of rift-filling volcanic rocks, was formed during the Rift Stage. This group has a thickness of over $12 \mathrm{~km}$ in some areas and features normal magnetic polarity (Huber, 1973).

As magmatic activity waned and eventually ceased, two additional stages occurred in the MRS timeline: the Post-Rift Stage ( 1083 to $\sim 1060 \mathrm{Ma})$ and the Compressional Stage ( 1060 to 1040 Ma) (Fig. 5; Woodruff et al., 2020). During the Post-Rift stage, thermal subsidence of the rift basin allowed deposition of a $\sim 7 \mathrm{~km}$ thick succession of clastic sedimentary rocks, known as the Oronto Group, whose deposition enhanced subsidence (Cannon et al., 1989). The Oronto Group consists of the Copper Harbor Conglomerate, the Nonesuch Shale, and the Freda Sandstone (Cannon and Hinze, 1992). The Copper Harbor Conglomerate is dominantly pebble to boulder conglomerate with clasts of Keweenawan volcanic rocks. The Nonesuch Shale is primarily gray, green, and brown lithic siltstone, shale, and sandstone, with copper sulfides and native copper occurring locally near the base of the formation. The Freda Sandstone is primarily a red-brown, medium-fine grained lithic arkosic sandstone, siltstone, and micaceous silty shale. The overlying load of volcanic and sedimentary rocks contributed to crustal subsidence, resulting in the modern structure of the Lake Superior syncline (Fig. 5A). 


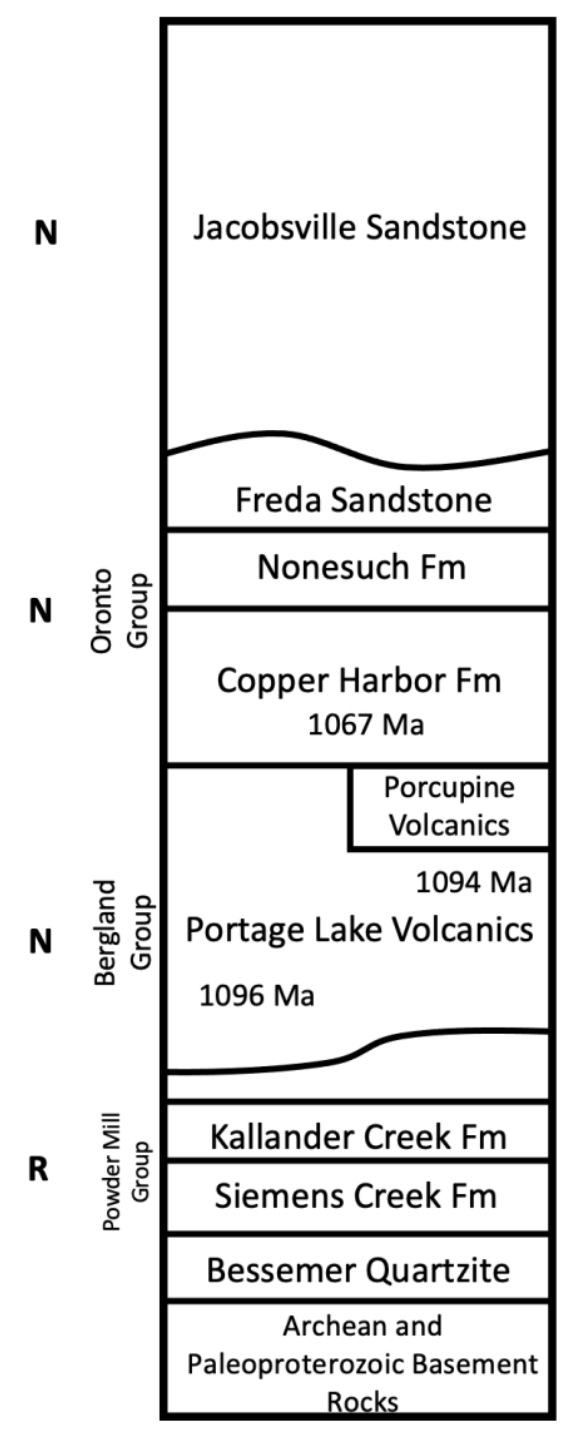

Figure 6: Stratigraphic column of the Western Upper Peninsula, Michigan, adapted from Kulakov, 2013. Radiometric ages are shown, along with ' $\mathrm{R}$ ' and ' $\mathrm{N}$ ' representing times of reversed and normal polarity (Davis and Paces, 1990).

The Portage Lake Volcanics (PLV) in the hanging-wall of the Keweenaw fault is the main rift-related rock unit of concern within the study area. This volcanic unit is a succession of tholeiitic flood basalts and rhyolitic domes erupted over a period of approximately 12 million years during the Rift Stage, with the majority of eruptions occurring during a 2 to 3 Ma period (Fig. 5; Davis and Paces, 1990; Woodruff et al., 2020). Total thickness of this 
unit, including interflow sediments, ranges from 2.5 to $5.2 \mathrm{~km}$ in the region, with columnar section indicating a thickness of approximately 3-5 km (White et al, 1952; Bornhorst et al.,1988; Cannon and Nicholson, 2001). The age of these rocks is well constrained by U$\mathrm{Pb}$ zircon dates, with peak magmatic eruption occurring between 1,093 and 1,091 $\mathrm{Ma}$ (Swanson-Hysell, 2019). PLV rocks have been hydrothermally altered, which is thought to have occurred within 31 to $44 \mathrm{Ma}$ of the last PLV eruptive activity (Bornhorst et al., 1988).

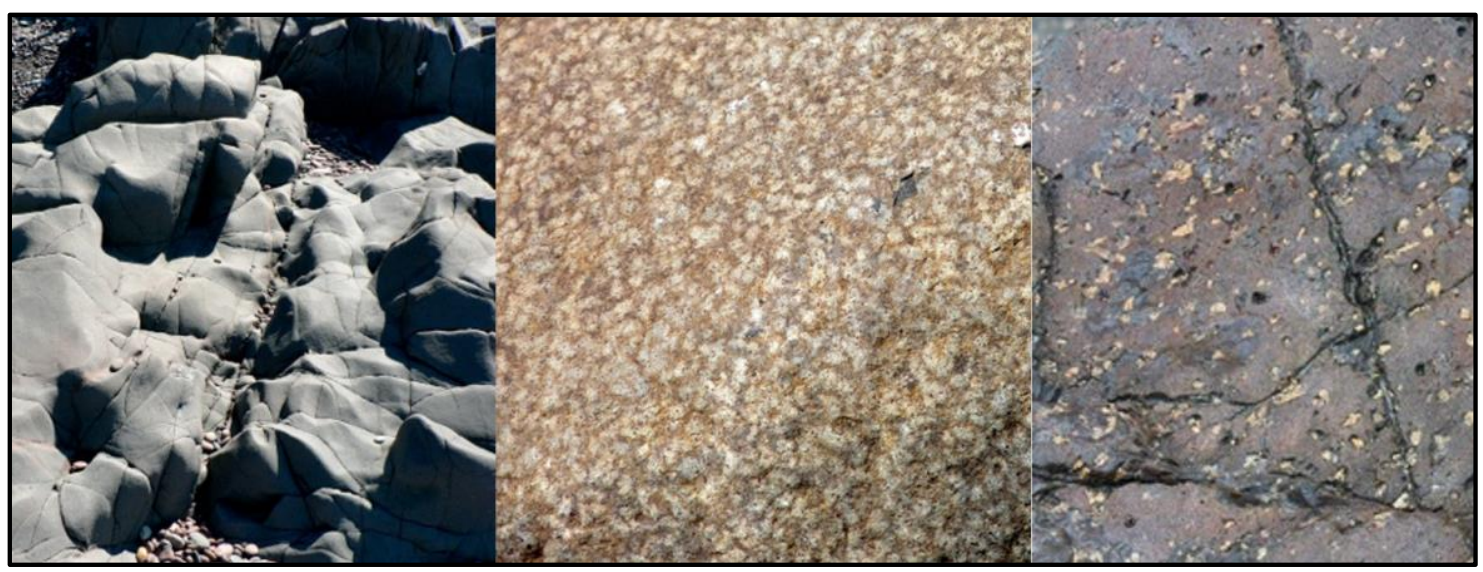

Figure 7: Main textural varieties of basalt observed in the study area. Left to Right: Massive, Ophitic, Amygdaloidal. Source: Keweenaw Geoheritage \& Michigan Technological University.

In the study area, the PLV mostly consists of mafic to intermediate lava flows and much smaller volumes of intermediate to felsic extrusive domes and pyroclastic deposits confined to the lower part of the section (Cannon and Nicholson, 2001). Basaltic to andesitic flows feature a variety of textures that result from variations in timing of eruption, cooling conditions, and composition. These textures serve as correlation indicators when moving from section to section and can be sorted into three broader categories: massive, 
ophitic, and amygdaloidal (Fig. 7; Butler and Burbank, 1929). Massive basalts, also known as melaphyres, are aphanitic and typically medium-dark purple grey in color and are indicative of the interior of a lava flow. Melaphyres are commonly found in the interiors of thinner flows, as well as flows that cooled and solidified relatively quickly, though some flows with thickness greater than 100 feet are classified as melaphyres. In thicker, slowercooling flows, pyroxene and feldspar crystals may grow larger and develop what is known as an 'ophite basalt'. Ophitic basalts feature pyroxene crystals that surround feldspar crystals, creating a roughly circular texture with patches (ophites) ranging in size from 3 millimeters to 2 centimeters, though they can be larger in thicker flows (Butler and Burbank, 1929). Ophitic texture is most easily recognized on a weathered surface, where the ophites protrude and create a knobby appearance.

Amygdaloidal texture is frequently observed near flow contacts, especially the upper one. Amygdules are vesicles formed when gas bubbles became trapped during solidification of lava, that have subsequently been filled by secondary mineralization. Amygdaloid abundance and mineral fill can be used as indicators of position within a flow. Sparse amygdules that primarily feature chlorite often indicate the bottom of a lava flow, whereas abundant, sometimes coalescing, amygdules with minerals such as epidote, calcite, quartz, copper, laumontite, microcline, prehnite, and pumpellyite are common near the top of a flow. Flow tops may have a reddish hue due to oxidation and may be weathered into coarse lithic sediment during breaks in eruption. They may also undergo brecciation during emplacement (auto-brecciation), which also promotes subsequent weathering (Cannon and 
Nicholson, 1992). These breccias, also known as fragmental flow tops, can be used as flow contact indicators.

Interflow sedimentary units found throughout the Portage Lake Volcanics, along with lava flows having distinctive textures, form the basis for stratigraphic correlation along the Keweenaw Peninsula. Thicker interflow sediments are especially well suited for correlation, but even they vary widely in thickness along strike and sometimes are not present. These sedimentary layers are primarily composed of conglomerate, though sandstone and conglomeratic sandstone occur frequently. Conglomerate clasts range in composition from mafic to felsic, derived from rift-related basalt and rhyolite units, vary in size from granule to cobble, and typically are subrounded to subangular (Cannon and Nicholson, 1990).; Associated sandstone layers often have conglomeratic stringers, display crossbedding, and occasional mud cracks. Interflow sedimentary units represent periods of waning or ceased magmatic activity, resulting in a dominance of sedimentary activity (Wolff and Huber, 1973). Depositional environment of interflow sediments is thought to be fluvial-lacustrine, with gradational layering visible at times (Jirsa, 1984). The Portage Lake Volcanics are overlain by the Copper Harbor Conglomerate, whose lithofacies are very similar to PLV interflow sedimentary layers. Thus, the Copper Harbor Conglomerate represents an overall decline in volcanic activity from PLV time without significant changes in depositional environment or sediment input. 


\subsection{Post-rift Crustal Shortening}

Subsequent to the thermal subsidence phase of rifting, the region underwent crustal shortening that produced a reverse component of slip on the Keweenaw fault and others like it in the Lake Superior basin. Two possible causes of this crustal shortening are the Grenville Orogeny ( 1200 - $980 \mathrm{Ma})$ and the Appalachian Orogeny ( 325 - $260 \mathrm{Ma})$, but both may have created or reactivated faults in the region (Spencer et al., 2015; Dallmeyer et al., 1986; Fig. 6). Timing of the Grenville Orogeny is roughly synchronous with Keweenawan rifting, leading some to suggest that Grenville compression caused extension of the Midcontinent rift to cease (Cannon, 1994; Gordon and Hempton, 1985). Recent updates on timing of Grenville rocks suggests that the orogenic event consisted of three main stages: Shawinigan (1200-1150 Ma), Ottawan (1080-1020 Ma), and Rigolet (1020$980 \mathrm{Ma}$ ). A compressional tectonic regime during the first two stages later transitioned to "Basin and Range" type extension in the Rigolet stage (Bartholomew and Hatcher, 2010).

The relationship of the Jacobsville Sandstone with the end-rift thermal subsidence and post-rift crustal shortening events is uncertain because age estimates of this unit range from 1060 Ma (Bornhorst, 1997; Cannon et al., 1993) to less than 960 Ma (Malone et al., 2016). The older proposed age would start Jacobsville deposition during the Ottawan phase of the Grenville Orogeny and during the thermal subsidence phase of the Midcontinent Rift System. However, recent detrital-zircon age studies suggest a maximum depositional age of $960 \mathrm{Ma}$ for the Jacobsville, which postdates all Grenville events and perhaps post-rift thermal subsidence, perhaps by up to 300 Ma (Malone et al., 2016). Additionally, 
deformation of Jacobsville Sandstone and overlying Paleozoic limestones at Limestone Mountain suggest that some slip along the Keweenaw fault occurred during the late Paleozoic Appalachian orogeny (Craddock et al., 1997; Malone et al., 2016).

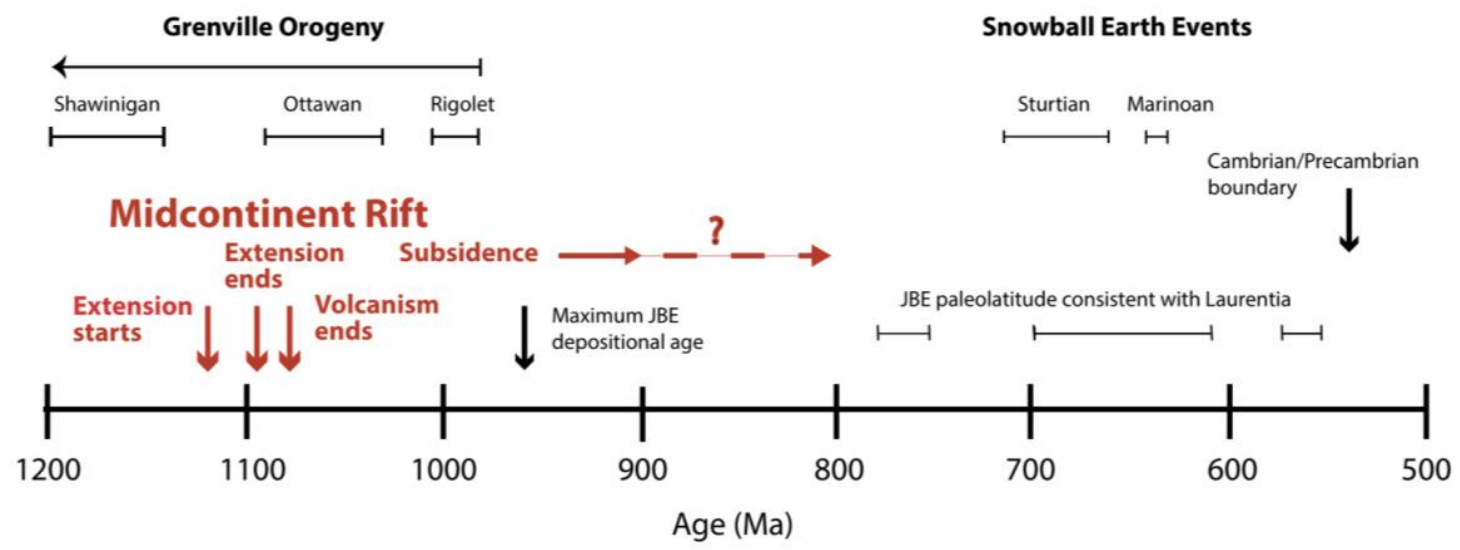

Figure 8: Timeline of the Midcontinent Rift System in relation to the Grenville Orogeny and other key geologic events. JBE represents the Jacobsville Sandstone, Bayfield Group, and other equivalent sedimentary rocks which overlie the volcanics and sediments deposited in the MCR basin (Malone et al., 2016).

The Jacobsville Sandstone is presumed to be stratigraphically equivalent to parts of the Bayfield Group in NW Wisconsin and other sandstones such as the Fond du Lac and Hinckley formations, all of which are referenced collectively as Jacobsville-Bayfield Equivalent (JBE) (Kalliokoski, 1982; Hamblin, 1958; Malone et al., 2016). Lithofacies and sedimentary features of the Jacobsville Sandstone are representative of terrestrial sediments deposited in fluvial to lacustrine environments. The Jacobsville sandstone often resembles the older Freda Sandstone in lithofacies, grain size, and coloration by exhibiting alternating bands of rusty red and opaque white. However, the Jacobsville is more mature in terms of texture and mineralogy than the Freda (Davis and Paces, 1990). The Jacobsville 
ranges from sub-arkose to quartz sub-lithic arenite, with sediments sourced from both volcanic and metamorphic environments. It mostly consists of terrestrial sandstone that is quartzose to feldspathic and relatively clean, but it also displays lithofacies that range from conglomerate to siltstone and shale. Conglomerate and conglomeratic sandstone mostly occur at or near the base of the formation and, in some instances, includes volcanic large basalt clasts cobbles likely derived from PLV strata.

\subsection{The Keweenaw Fault}

Studies of the relationship between PLV on the northwest side of the Keweenaw Peninsula and JS on the southeast side date back to the mid-1800s when geologists began investigating copper deposits in the area. Irving and Chamberlin (1885) effectively resolved early debate about the nature of the PLV-JS contact along the Keweenaw Peninsula with detailed observations indicating a faulted contact. In outcrop and at several excavations across the PLV-JS contact, they observed fault gouge, brecciated volcanic rock, secondary mineralization, and highly tilted JS strata, all of which supported their interpretation of a fault contact between PLV and JS. This conclusion has been substantiated by subsequent geologic work and has been applied everywhere on the Keweenaw Peninsula where PLV and JS are in close proximity. Since Irving and Chamberlin's report the PLV/JS contact along the Keweenaw Peninsula has been drawn as the Keweenaw fault.

In their report on the copper deposits of Michigan, Butler and Burbank (1929) described the Keweenaw fault as a reverse fault with general northwesterly dip that is nearly parallel 
to the dip of PLV strata, an observation previously made by Hubbard (1898). Butler and Burbank (1929) further noted Hubbard's (1898) observations of slip between PLV layers and reported branch faults and fissures associated with the main Keweenaw fault. The Keweenaw Fault and the Lake Superior syncline were identified as the dominant structural features of the region, and the syncline was classified as asymmetrical with more steeply dipping beds on the south limb. They reported observations of the Portage Lake Volcanics placed on top of the Jacobsville, which they presumed to be a product of reverse movement along the Keweenaw Fault, as well as fold deformation in the Jacobsville Sandstone. These observations led to the conclusion that deposition of the Jacobsville occurred simultaneous with movement on the Keweenaw Fault, and that movement along the fault continued after deposition. Although they could not determine the exact cause and timing of deformation, they were confident that evolution of the Lake Superior syncline took place slowly during Keweenawan time. They assumed that the Lake Superior basin was forming while JS was being deposited unconformably upon Keweenawan beds. This assumption implies fault movement beginning in Keweenawan time and continuing until after Jacobsville deposition, resulting in the folding of JS strata observed in the footwall.

These geological concepts, as well as mining exploration and production data, were later incorporated into United States Geological Survey (USGS) bedrock geology maps published in the 1950s. The USGS maps portray the Keweenaw fault as a relatively continuous thrust with a sinuous trace along the Keweenaw Peninsula, associated with smaller subparallel faults. These maps provide much more detail than earlier maps and they include many cross-sections that incorporate surface mapping and information from mines 
and exploratory drill holes. Between Mohawk and Lac La Belle, Michigan, the new crosssections depict a relatively simple structural scenario, featuring moderate, homoclinal dip in the hanging wall of the fault that shallows northwest towards Lake Superior (Fig. 2). Although some cross-sections show folding in the hanging wall near the Keweenaw fault, little structural analysis and no quantitative characterization of faults and folds has been performed in this area. These published USGS maps provide a good baseline for general geology and fault location, but they do not address questions about fault geometry, slip kinematics, and slip timing.

Since about 1970 when the MRS was being recognized, much debate has centered around fault origin, timing, and slip direction. Before that time, the Keweenaw fault was defined as a simple reverse or thrust fault that formed in a compressional stress regime that followed formation of the Lake Superior basin. Recognition of the MRS led to the idea that the fault originated as a normal fault during rifting, with subsequent forces from the Grenville Orogeny $(1.25-0.98 \mathrm{Ga})$ reactivating the earlier normal fault as a reverse fault (Cannon and Nicholson, 2001, Hinze et al., 1990). Despite this more recent idea becoming generally accepted, the nature and timing of fault movement, particularly in relation to JS deposition, remains a topic of debate. Until recently, the fault was considered to be a thrust fault that potentially initiated as a normal fault (Irving and Chamberlin, 1885; Cannon and Nicholson, 2001); however, new studies indicate a segmented fault system with different fault segments moving at different times, with significant strike-slip indications present (DeGraff et al., 2018). 
Irving and Chamberlin (1885) thought that the fault moved twice as a thrust fault, both before and after JS deposition. Cannon and Nicholson (2001) thought the fault initiated as a graben-bounding normal fault that was later reactivated as a thrust fault simultaneous with JS deposition. More recent studies indicate a segmented fault system with different fault segments moving at different times, with significant strike-slip indications present (DeGraff et al., 2018).

Debate is ongoing about timing related to the deposition and deformation of Precambrian sedimentary units. The most recent effort to define the geometry and slip kinematics of the Keweenaw fault, and thus to infer its nature, is a prior EDMAP project completed in 2018 (DeGraff et al., 2018; Tyrrell, 2019). That mapping project was conducted along a segment of the Keweenaw fault running from Bête Gris Bay to the tip of the Keweenaw Peninsula where the fault submerges offshore in Lake Superior. Results suggest a segmented fault system comprised of multiple smaller faults, exhibiting both strike-slip and dip-slip components (DeGraff et al., 2018). The study concluded with evidence supporting PLV deformation mostly occurring prior to JS deposition, with some deformation occurring after JS deposition.

The MS thesis research presented here is based upon the 2019-2020 EDMAP project, a continuation of the 2017-2018 EDMAP project. The specific aims of this MS project are as follows:

\section{Interpret the new map geometry of the KF system in terms of implied fault kinematics}

and related stratal deformation. Fault slip kinematics should vary as a function of fault 
orientation relative to shortening direction. Overall geometry of the fault system and patterns within it provide information about the tectonic regime responsible for faulting.

Explain variations in fold geometry according to slip on different fault trends. A fault system featuring varying segment orientations and slip components has implications for local folding and regional deformation. Comparing fold orientations to adjacent fault orientations provides insight about the causes of local folding and regional paleostressstrain directions during periods of active faulting.

Analyze slip kinematics and large-scale deformation in terms of tectonic events and forces. Kinematic slip indicators vary as a function of fault orientation and shortening direction. These small-scale indicators can be used in conjunction with observations of regional deformation to further investigate regional axes of maximum strain. 


\section{Methods, Materials, and Equipment}

The project reported here consisted of field work, preparation of geologic maps and cross sections, sample preparation and lab analysis, and structural analysis of deformation and kinematic data. Substantial preparation and planning were required before beginning fieldwork. An ArcMap project file for the map work was created and organized using the USGS mapping package toolkit, modified to reflect local geology. Shapefiles of Keweenaw Peninsula geology (Cannon et al., 1999) were downloaded from the USGS website and imported into the ArcMap document. Older geologic maps were scanned and georegistered in order to use them in ArcMap and Google Earth Pro. Reconnaissance work included preliminary field site visits, a literature review, and scouting by means of satellite and aerial imagery, all of which helped with identifying and selecting high-priority target areas to visit during fieldwork. Orientation meetings with the two project teams covered objectives, field methods, and safety concerns and protocols. The first two weeks of field work focused on establishing in-situ field practices and standardizing operations between teams. This training period promoted consistent field decisions and data collection by the teams in order to facilitate data integration and final map preparation. 


\subsection{Field Operations}

Field work largely followed traditional mapping procedures while taking advantage of advancements in technology and in understanding of tectonics and fault kinematics since previous mapping in the 1950s. Use of rock hammers, chisels, Brunton Transit compasses, and hand lenses was combined with submeter-precision Trimble dGPS technology and phone-based applications for geospatial location and orientation measurements. Previous geological mappers had to rely on physical base maps, aerial photos, and compass-pace work to navigate in the field and to position outcrops on a map. This project used the Avenza Maps iOS application to track location in real time and to relocate outcrops shown on older geologic maps imported into the application. This project also utilized the Field Move Clino iOS application along with a Brunton compass to measure orientations of surfaces and lines.

Prior to fieldwork, a data dictionary was created and installed on the Trimble Geo7x dGPS units used to collect geospatial coordinates of field sites. The data dictionary enabled onsite digital input of exposure type, lithology, contact type, structural features, and brief notes, all of which were cross-referenced to detailed notes and sketches for the same site in the field book. Capturing basic site and geologic data digitally in real time facilitated the transfer of field data to ArcMap using a data attribute table. Field data recorded in a traditional notebook were transferred manually to Excel spreadsheets.

A typical field day began at a staging location where the day's objectives, logistics, and safety issues were reviewed and discussed. Prior to starting work, a page was created in 
the field book with the date, area worked, personnel, and objectives for the day. Most days involved visits to multiple field sites, so an operations plan was discussed to efficiently visit sites, to consider alternatives in case of unforeseen circumstances, and to exit the area by a predetermined time. At each field site, a general site description was recorded in the field book under a unique sequential site number that also was assigned to the geospatial coordinates acquired with the Trimble dGPS unit. Basic geologic data were captured using the Trimble's data dictionary while a full geologic description was recorded systematically in the field book (Table 1). Hand samples collected for lab work were labeled, bagged, and recorded in the field book. 
Table 1: Data Recorded in Field Book

\begin{tabular}{|l|l|l|}
\hline Data Type & Description \\
\hline Site Number & Sequential number that uniquely identifies the site throughout data processing. \\
\hline Setting & $\begin{array}{l}\text { Distance from nearby sites (when applicable), topographic position, notable } \\
\text { features such as breaks in topography, sharp drainage bends, cultural reference } \\
\text { points }\end{array}$ \\
\hline $\begin{array}{l}\text { Exposure } \\
\text { Type }\end{array}$ & $\begin{array}{l}\text { Nature of exposure (outcrop, subcrop, float), dimensions, presence of contacts } \\
\text { and structures, where GPS coordinates were collected }\end{array}$ \\
\hline Lithology & $\begin{array}{l}\text { Hand sample description } \\
\text { of main rock types; notes } \\
\text { when samples are } \\
\text { collected. }\end{array}$ & $\begin{array}{l}\text { Igneous rocks: color, texture, grain size, mineral } \\
\text { components (groundmass, amygdules), secondary } \\
\text { mineralization }\end{array}$ \\
\cline { 2 - 3 } & $\begin{array}{l}\text { Sedimentary rocks: color, grain size, rounding, } \\
\text { sorting, induration, grain components, bedding } \\
\text { style and scale, sedimentary features }\end{array}$ \\
\hline $\begin{array}{l}\text { Structural } \\
\text { Features }\end{array}$ & $\begin{array}{l}\text { Structures present at the site such as tilted strata, folding, faults, joints, and } \\
\text { veins; describes features and relationships between them. }\end{array}$ \\
\hline $\begin{array}{l}\text { Structural } \\
\text { Measurements }\end{array}$ & $\begin{array}{l}\text { If applicable, strike-dip of surfaces, rake or plunge-azimuth of lineations, and } \\
\text { trend of poorly exposed structures; identifies each feature measured, its } \\
\text { characteristics, measurement method, confidence, and the measurer. }\end{array}$ \\
\hline
\end{tabular}

During the 2019-2020 EdMap project, orientations of over 1,600 surfaces and lineations were measured, which provides a robust dataset for structural analysis. Orientations generally were made with a Brunton International Transit compass, but FieldMOVE Clino was used where the Brunton was difficult to use, such as in shallow underhangs, narrow spaces, or areas with magnetic anomalies. Strike and dip measurements of bedding revealed regional changes in bedding orientation useful in regional strata correlation and allowed identification and structural analysis of folds near the Keweenaw fault. Measurements of lineation rake on fault surfaces provided information about fault slip 
characteristics of use in paleo-stress-strain analysis. Each orientation measurement includes metadata about who made the measurement, method used (direct surface contact, indirect contact, sight line), tool used (Brunton, FieldMOVE Clino), confidence in the measurement (high, medium, low), and comments about surface or lineation characteristics. Measurement confidence is based on the quality of the feature and the ease or difficulty experienced by the geologist making the measurement. For example, measurements on well-exposed smooth bedding surfaces generally will have higher confidence than measurements made on surfaces that are poorly exposed or have undulations. Similarly, a geologist making measurements in a stable comfortable position with good lighting generally will have more confidence than one making measurements in a contorted position, in shadows, or from a distance.

\subsection{Data Management and Analysis}

Field data were captured, formatted, and processed in the office using separate workflows for geologic and geospatial data (Figs. 9 and 10) gathered at over 1,790 field sites. The large quantity and variety of data collected each day demanded regular data upkeep to ensure data quality and prevent becoming overwhelmed. Geospatial data was imported into Google Earth Pro on a daily basis and into ArcMap typically 1-2 times per week. Information recorded in the field book was transcribed into Excel spreadsheets typically 12 times per week. 


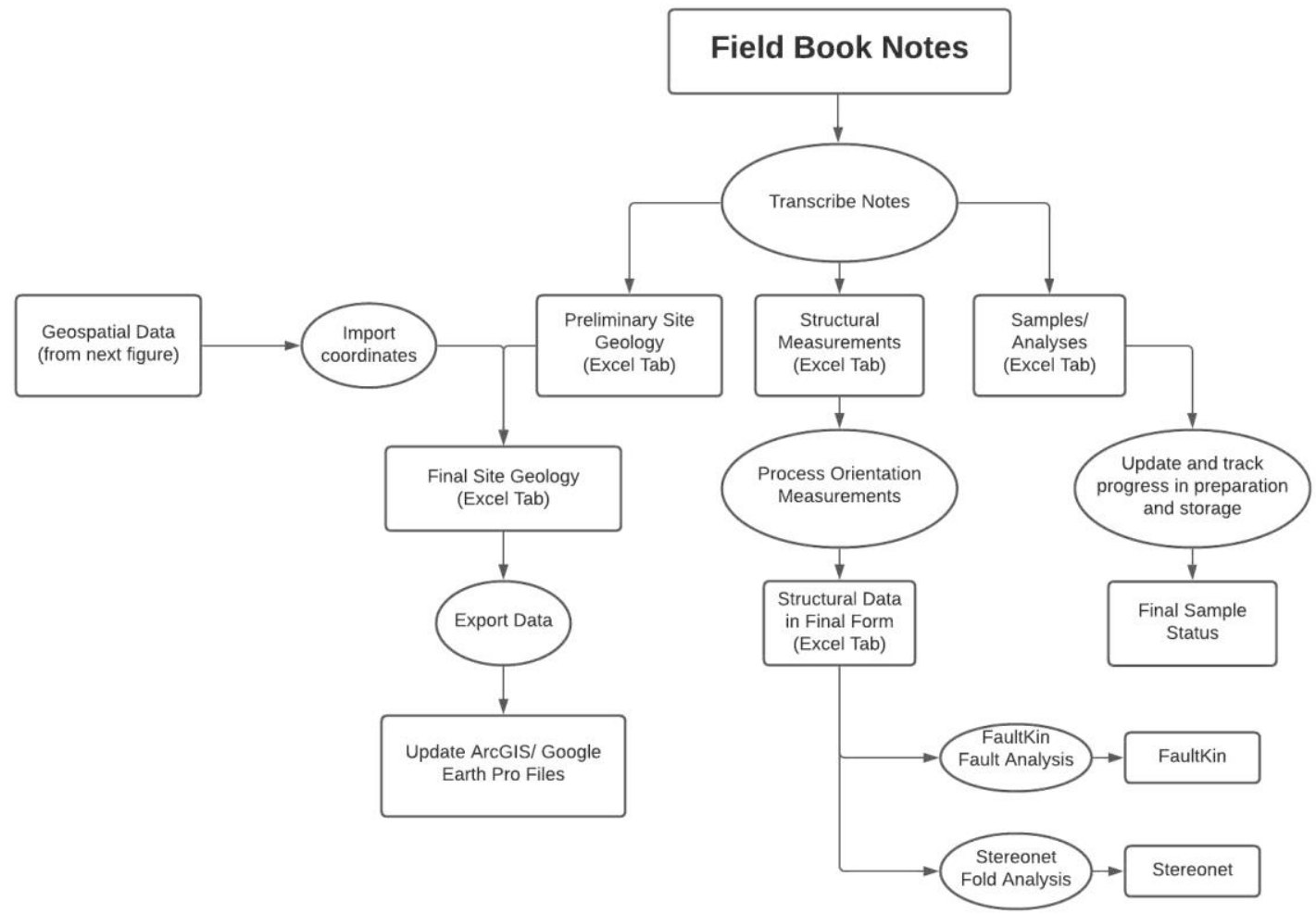

Figure 9: Workflow for geologic data transcription, organization, and analysis. 


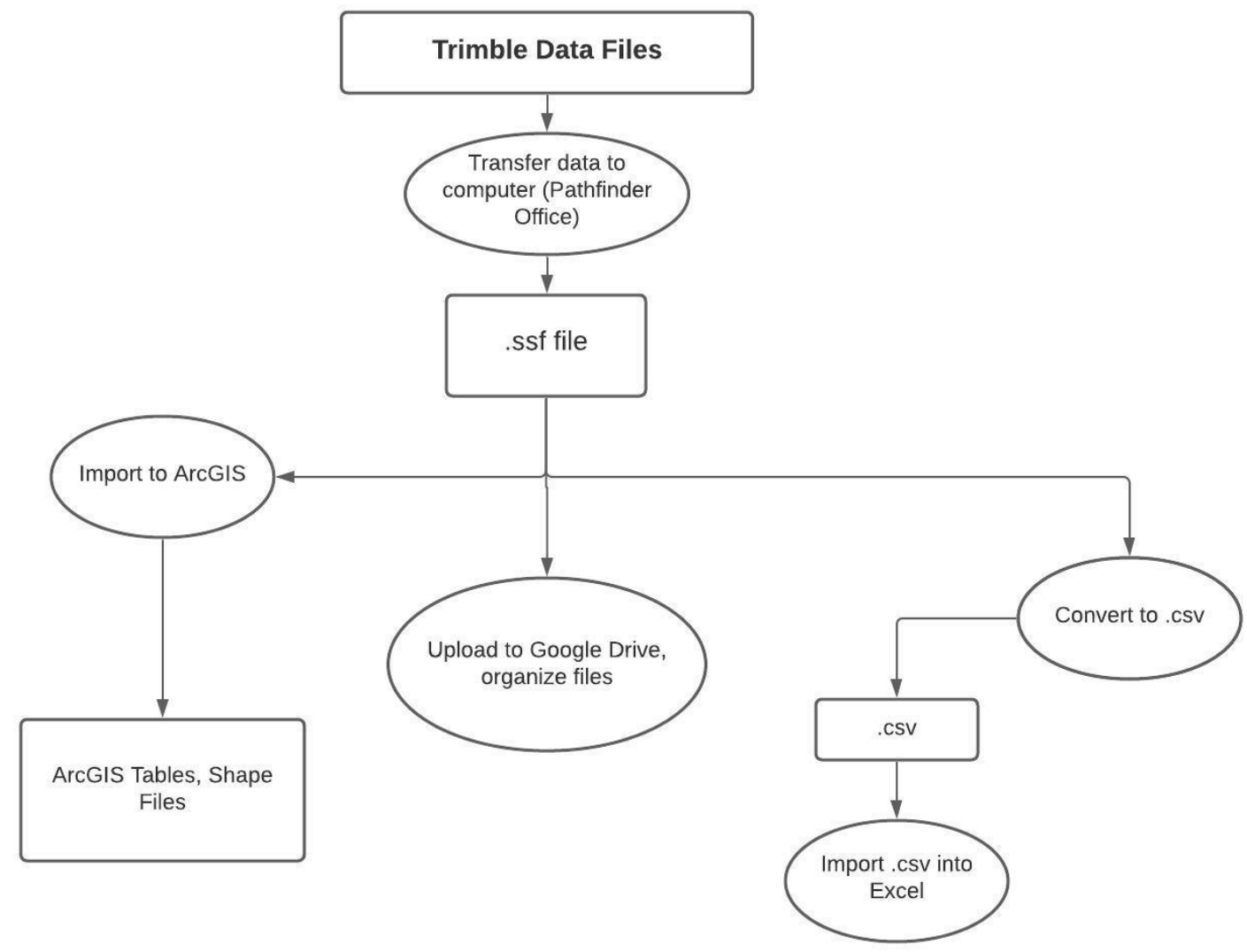

Figure 10: Workflow for geospatial data importation and visualization in ArcMap.

Geologic data recorded in the field book were routinely transcribed into Excel spreadsheets (Fig. 9) to stay current with the data flow, and field books were scanned periodically to create backup copies in case a book was lost or ruined. Data transcription on a regular basis improved data organization and tracking of hand sample preparation and storage. Field notes were transcribed into an Excel spreadsheet with three sections (tabs): one for most geologic site observations, another for structural orientations, and a third for samples and subsequent lab work. 
Geospatial data acquired with Trimble Geo7x dGPS units were automatically associated with site information input by means of the data dictionary. This facility made data collection relatively easy. Problems collecting good geospatial data occasionally resulted from poor satellite reception as a result of low signal strength due to steep topography, cloud cover, or moisture on foliage following a rainstorm. Geospatial coordinates were transferred from the Trimble Geo7x into Google Earth Pro on a daily basis to visualize progress and plan next-day fieldwork (Fig. 10).

Structural orientation measurements were also routinely transcribed into a tab in the Excel data file and organized based on measurement type and site number. Raw measurements were combined by averaging at various stages in data processing. Duplicate measurements made on the same surface were averaged first to yield a single characteristic measurement for the surface. Duplicate measurements occurred when two geologists measured the same feature or if repeat measurements were made using different methods or tools. A second step of averaging was used to calculate site-averaged strike and dip when multiple bedding surfaces were measured at the same site. The two software programs used to display and analyze the structural data were downloaded from Richard Allmendinger's website at Cornell University (Allmendinger, 2020). Bedding orientation data was input into Stereonet to analyze fold geometry and calculate fold axis and axial plane orientations. Processed and averaged slip lineation measurements were imported into FaultKin to identify patterns of slip direction and to infer paleostress and fault kinematics. 


\subsection{Sample Preparation and Analysis}

Over 460 rock samples collected during fieldwork were processed in the rock preparation lab in the DOW Building at MTU. Most samples were cut to observe their unweathered interiors and to update field determinations of rock type if necessary. This reexamination of lithology on freshly cut surfaces often improved the identification of rock type because weathered outcrop surfaces in dim light often inhibit distinguishing rock types like interflow sedimentary units and flow-top breccias. Samples of particular interest or hard to identify were cut for thin sections and examined petrographically. Most thin sections were made in the MTU rock preparation lab, but some samples were sent to Wagner Petrographic LLC in Utah for thin-section preparation.

A smaller number of samples were sent to ALS Global in Nevada for full geochemical analysis and to Zirchron in Arizona for separation of zircon and other minerals suitable for radiometric age dating. Geochemical analysis was done on uncommon rocks such as porphyritic rocks with an intermediate appearance near the Suffolk location and two intrusive phases at Mt. Bohemia (Fig. 12). Zircon has been separated from the Mt. Bohemia rocks and will be submitted for radiometric age dating, but results will not be available before late 2021 . 


\section{Results and Findings}

This thesis project and another were funded by the USGS EdMap program, which requires a geologic map and accompanying report to be submitted for the area of investigation at the end of the project. The EdMap-funded project, completed in August 2020, involved two M.S. students mapping for two field seasons to cover the area outlined in Fig. 11. Daniel Lizzadro-McPherson (DJLM) was primarily responsible for mapping the eastern part of the project area, while I (SAM) was primarily responsible for the western part, though we overlapped in practice during the mapping. Results of the collaborative project were reported to the USGS as the map of Fig. 12 and in a technical report with smaller detailed maps covering areas of particular structural interest (DeGraff et al, 2020). The M.S. project presented here is derived from the EdMap work and focuses on structural details in the areas near $\mathrm{B}$ and $\mathrm{C}$ on the figures. To put detailed structural results of this thesis into perspective, I first summarize the general results of the collaborative EdMap project. 


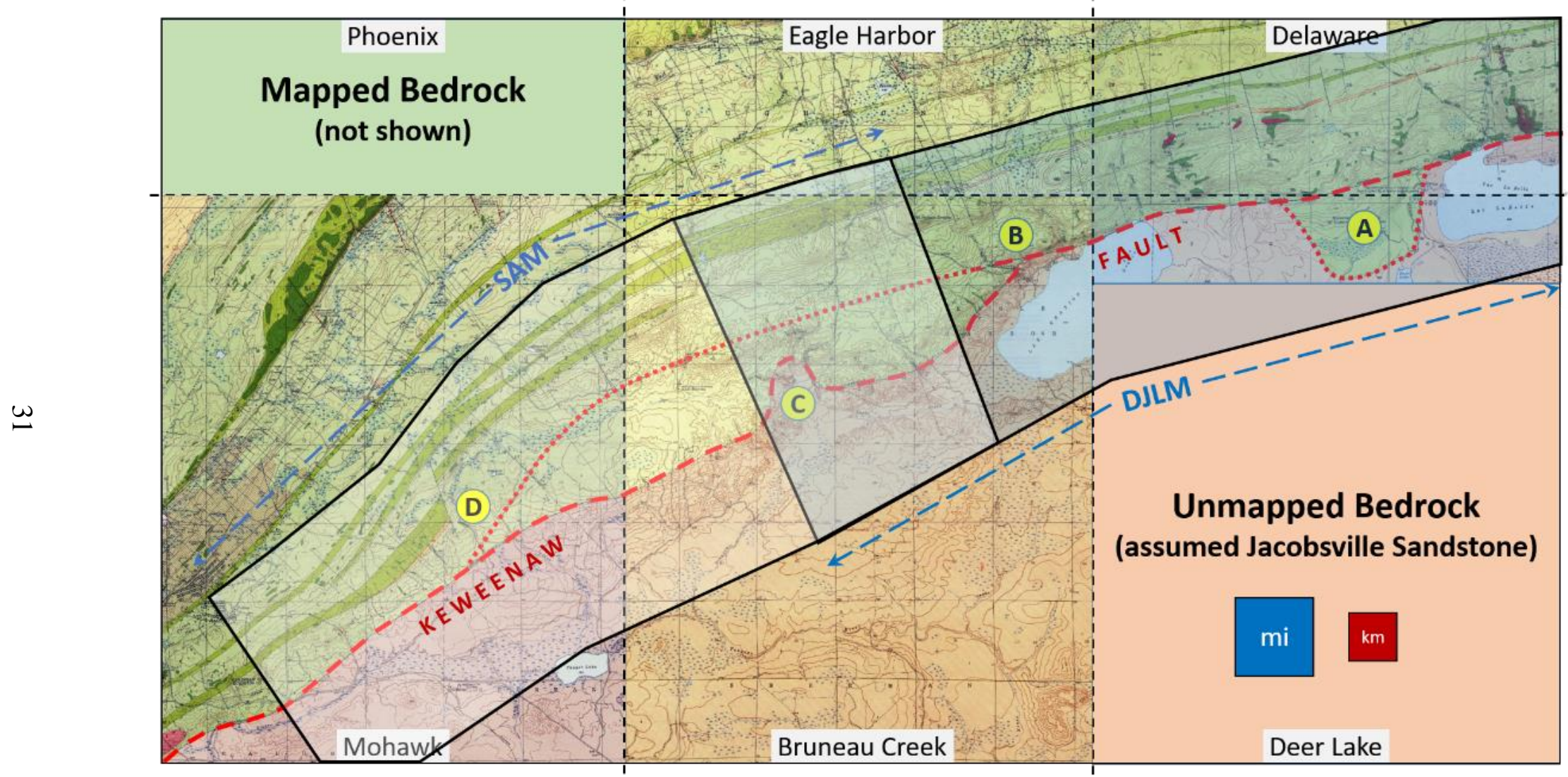

Figure 11: Compiled 7.5-minute bedrock geology quadrangles of Cornwall (1954), Cornwall and Wright (1954), Davidson et al. (1955), and Wright and Cornwall (1954). EdMap project area is outlined by a black perimeter; areas of mapping responsibility are indicated by initials DJLM (Lizzadro-McPherson) and SAM (Mueller). Portage Lake Volcanics with green tones occur northwest of the Keweenaw fault in the hanging wall; Jacobsville Sandstone in light orange to pink tones occurs southeast of the fault in the footwall. 


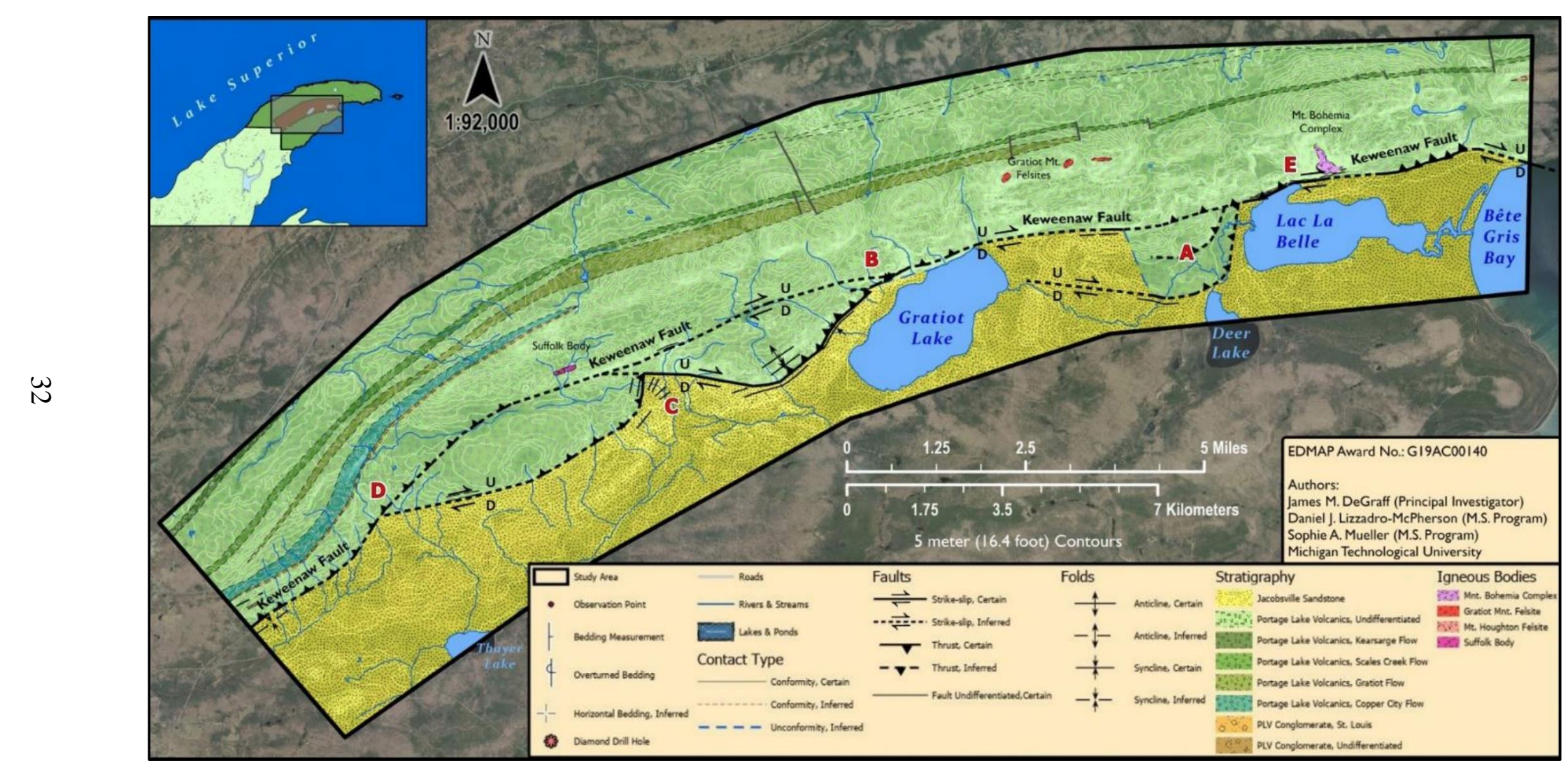

Figure 12: Updated bedrock geology map of the EdMap project area. Map legend here applies to subsequent detailed maps of focus areas (red letters). Opposing arrows indicate sense of strike slip on faults; letters "U" and "D" denote relative upward and downward dip slip. 


\subsection{EdMap Project Area: Summary of Fault and Fold Patterns}

The 2019-2020 EdMap campaign focused on a segment of the Keweenaw fault spanning from Mohawk to Bête Gris Bay, Michigan in order to test and build on a new understanding of fault system geometry and kinematics from a preceding EdMap project (DeGraff et al., 2018; Tyrrell, 2019). New mapping reveals that the Keweenaw fault in both project areas is better characterized as a fault system composed of many connected fault segments (Fig. 12), rather than a single, sinuous fault trace as has been depicted on earlier maps (Fig. 11). The new detailed mapping resolves this segmented fault geometry in part by better defining the PLV-JS contact, which in places has been moved up to $400 \mathrm{~m}$, and in part by identifying major faults that juxtapose PLV on both sides (Fig. 12). These changes in mapped fault system geometry force a revision of previous interpretations and have bearing on the tectonic forces that led to such faulting.

Our new field data define a Keweenaw fault system composed of fault segments that generally fall into three categories: 1. ENE-trending segments parallel to the fault system's overall trend; 2. ESE-trending segments with an en echelon arrangement especially toward the east; 3. NNE-trending segments that connect faults of the first two categories (Fig. 12; DeGraff et al., 2020). Together, these fault sets define a zigzag pattern of connected faults that bound fault blocks elongated parallel to the Keweenaw fault system. The longest faults are ENE-trending Set 1 faults that define the overall trend of the fault system. Set 2 faults are major faults like those of Set 1 but are shorter and display a left-stepping pattern. Set 3 faults are even shorter fault segments that intersect the longer faults at relatively high 
angles, nearly $90^{\circ}$ in places, and either end against them or curve to merge with them. This fault system geometry defines a connected system with a tendency for left-stepping segments, similar to what was inferred for the 2017-2018 EdMap project area (DeGraff et al., 2018). Fault-bounded blocks of PLV strata within the fault system are hypothesized to have displaced east-northeast along the longer faults (sets 1 and 2) and thrust eastward along the shorter faults (set 3).

The new mapping has also revealed hanging-wall and footwall folding along many segments of the Keweenaw fault system (Fig. 12). The hanging-wall folds are newly defined whereas some footwall folds had been recognized previously but were poorly resolved. Fold axes typically are subparallel to adjacent faults, i.e., NE-trending folds occur along faults with a similar trend, which is consistent with results of the 2017-2018 EdMap project. Fold style and intensity appear to vary as a function of adjacent fault type and trend. Folds in hanging-wall and footwall positions in the same area may have different orientations, but they still tend to be genetically related to nearby fault trends. The relationships between fault and fold orientation suggests an overall WNW shortening direction during regional deformation, as explored more fully in the next section.

This paleostrain inference is supported by measured fault-slip indicators, analyzed in Section 5, which show evidence of significant strike slip and a lesser amount of dip slip within the fault system. Strike-slip indicators are mostly observed along ENE- and ESEtrending faults, with both right-lateral and left-lateral sense of slip inferred from asymmetry of surface steps. Field measurements of fault-slip indicators do not adequately sample NNE-trending faults, so the inference of mostly dip slip on these faults is supported by drill 
hole data and nearby fold geometry. The small-scale fault-slip indicators provide further evidence of a regional WNW shortening direction responsible for the map pattern of faults and folds (Fig. 12).

\subsection{Focus Area West of Lake Gratiot: Map Changes and Structural Geometries}

The fault pattern and resulting fault blocks west of Lake Gratiot provide excellent examples of the variety of fault and fold styles present in the larger area. For this reason, I chose to analyze structural relationships within this focus area (Fig. 13) in more detail using map patterns, cross-sections, and tools for stereonet analysis and fault-slip inversion.

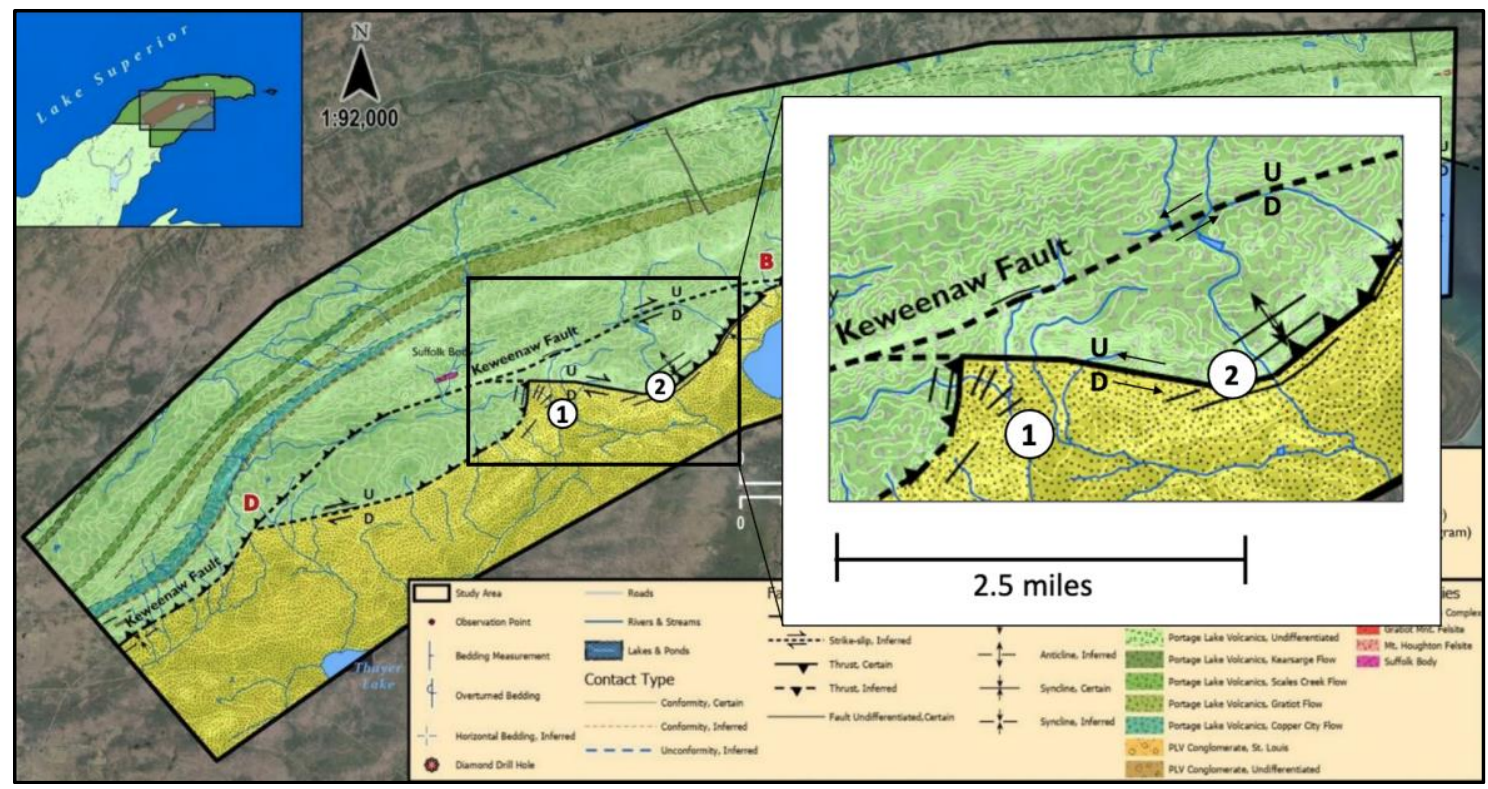

Figure 13: EdMap project geology map with MS thesis focus area outlined and enlarged in inset.

The three fault orientations composing the Keweenaw fault system are present in the focus area and define two major fault blocks whose edges are dissected by numerous drainage 
systems (Fig. 13). Downcutting along the drainages has created several stretches of nearly continuous or frequent outcrops for description and structural measurements, especially along Bruneau Creek (Fig. 13, location 1) and an eastern tributary of Snake Creek (Fig. 13, location 2). Published USGS maps show the fault trace in this area as having a deep reentrant of JS northward into PLV with a nearly $180^{\circ}$ change in direction of the PLV-JS contact (Fig. 14A). In inactive thrust fault terranes such as the Appalachian Mountains, reentrant geometries result from erosion through the edge of shallow-dipping thrust sheets to expose the underlying footwall lithology. Thus, the reentrant fault geometry shown on the published map implies a thrust fault dipping shallowly northward. 

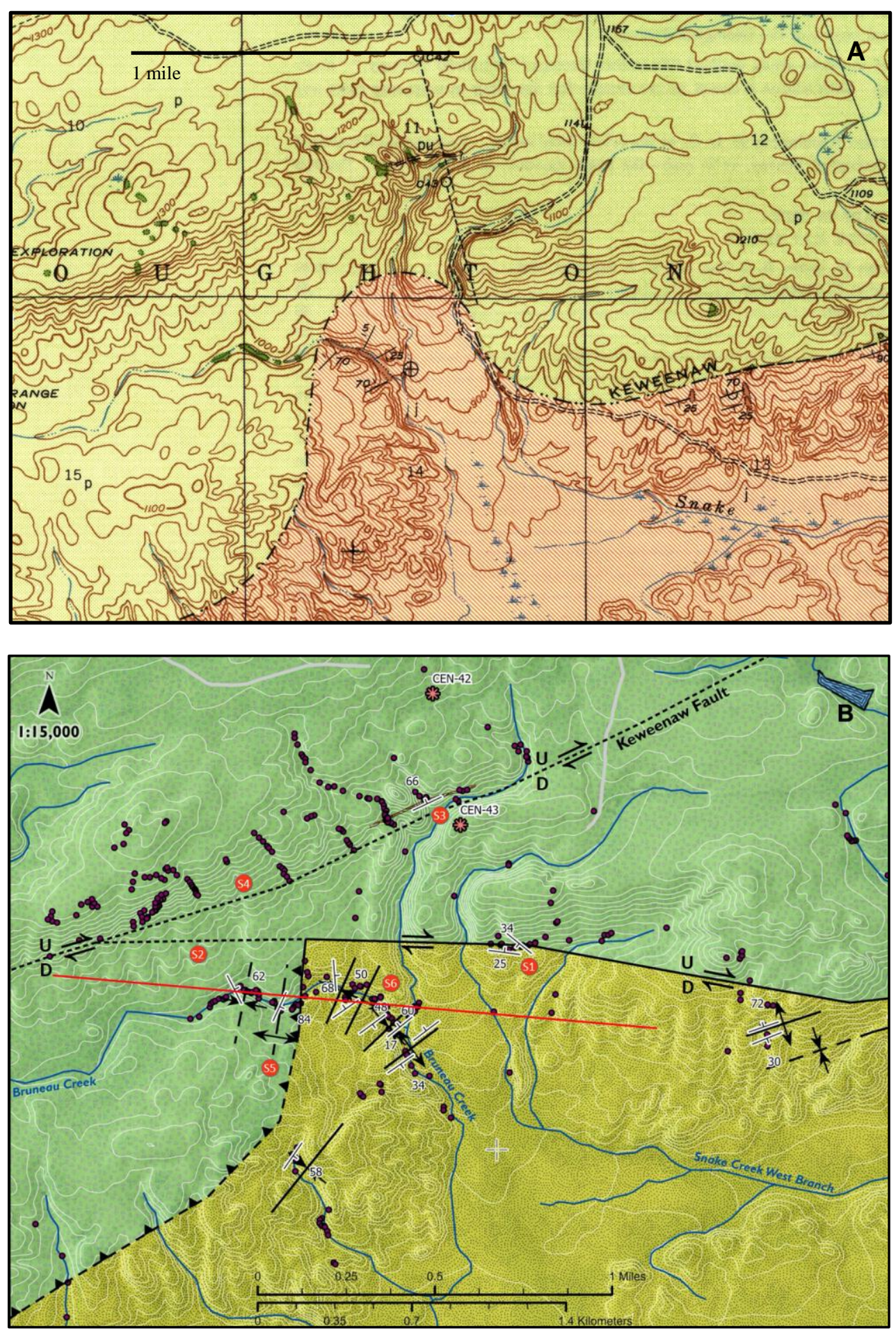

Figure 14: A. Published USGS bedrock geology map for Area 1 near where Bruneau and Snake creeks cut across the PLV-JS contact (Wright and Cornwall, 1954) B. New bedrock geology map showing multiple fault segments and outcrop data points as black dots. Opposing arrows indicate sense of strike slip on faults; letters "U" and "D" denote relative upward and downward dip slip. Red flower shapes refer to diamond drillhole locations. Red line denotes cross-section extent. 
New mapping has refined the location and extent of known outcrops and has located new outcrops that modify the location and geometry of the PLV-JS contact to such a degree that the reentrant no longer exists (Fig. 14). Instead, the PLV-JS contact geometry here now defines a triangular area of JS with nearly perpendicular northern and western sides controlled by fault segments of Sets 2 and 3. The northern fault at the top of the triangle extends east-southeast to the east branch of Snake Creek (Fig. 13, location 2). The path of this fault is well constrained by neighboring PLV and JS outcrops at several locations and by JS strata tilted steeply southward near the fault trace. Although kinematic slip indicators were not found along this fault segment, its western end probably intersects the main fault in the area (labeled Keweenaw Fault in Fig. 13), which is associated with faults having indications of right-lateral strike slip. Thus, the northern fault of the triangle most likely has a strong component of right-lateral strike slip.

Along Bruneau Creek near the western fault segment, new mapping has defined fold geometry in JS, in contrast to the confusing strike-dip pattern of the published map and has identified folding and faulting of PLV in the hanging-wall. Here, a sequence of three synclines and two anticlines in the Jacobsville Sandstone is arrayed in a fan-like arrangement with fold axes oriented generally to the northeast (Figure 14). Most JS strata here are the typical lithofacies consisting of fine-medium grained, medium-well sorted, well indurated subarkose to quartz sublithic arenite. Near the mapped PLV-JS contact, however, outcrops of muddy, poorly indurated and recessive, conglomeratic units were found, often by excavation, near the inferred base of the Jacobsville Sandstone. This JS lithofacies is not commonly found in outcrop as it is easily eroded, but along Bête Grise 
Bay to the west it crops out at the PLV-JS unconformity (DeGraff et al., 2018) where it defines a ductile basal unit of the Jacobsville Sandstone. West of the PLV-JS contact by about $60 \mathrm{~m}$, a critical PLV outcrop in the south bank of Bruneau Creek was discovered, excavated, and measured (Figure 15). Here, a fault $\left(\mathrm{S} / \mathrm{D}=185^{\circ} / 32^{\circ} \mathrm{W}\right.$ ) striking parallel to the mapped PLV-JS contact has mostly intact PLV strata in its hanging-wall that are nearly parallel to the fault surface. In the footwall of the fault, a subvertical PLV conglomerate layer $\left(\mathrm{S} / \mathrm{D}=185^{\circ} / 84^{\circ} \mathrm{W}\right)$ is overlain to the east by similarly oriented, fractured, basaltic flows that are often highly brecciated. These relationships strongly suggest that the PLVJS contact here is a major fault that thrusts PLV eastward over JS strata, partly explaining the observed JS folding.

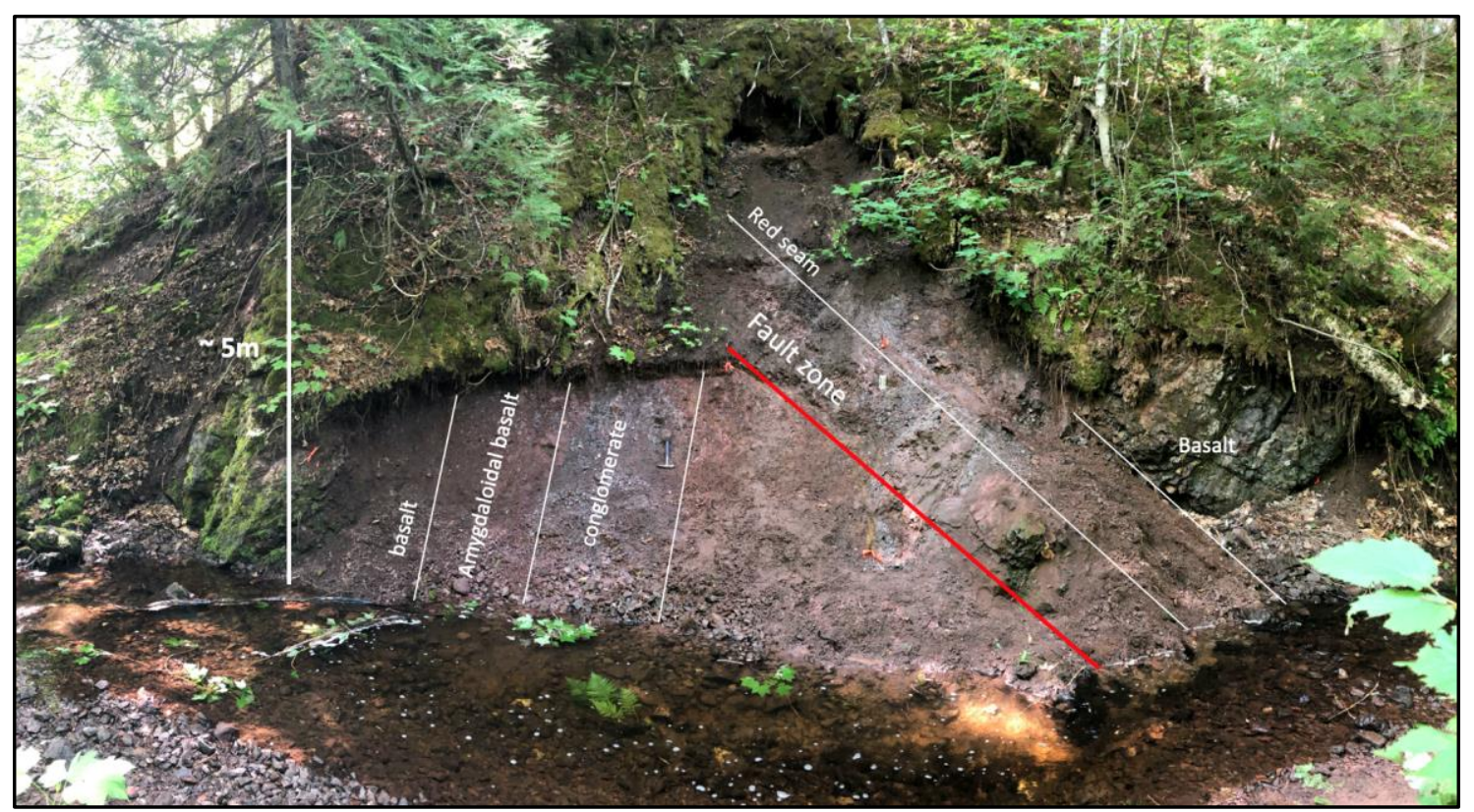

Figure 15: Picture of fault excavated at Bruneau Creek. Look direction is $185^{\circ}$.

The mapped PLV-JS contact elsewhere in the area (Fig. 13) also has been modified by the new mapping, but the overall geometry of the contact is not much changed away from the 
former reentrant. What has changed significantly is definition of fold geometry both in the footwall and hanging-wall of the fault segments. The east branch of Snake Creek, located $1.6 \mathrm{~km}$ west of Lake Gratiot, cuts across a sharp bend in the PLV-JS contact where two fault trends intersect or merge (Fig. 16). Northeast of this Snake Creek branch, the main PLV-JS contact is well-constrained by the distribution of PLV and JS outcrops and is interpreted to be a thrust fault based on northeast-trending fold axes in the hanging wall and steep southeast tilt of JS strata in the footwall. The hanging-wall anticline-syncline pair, defined by interflow sandstone and conglomerate, have axes plunging $23^{\circ}$ northeast at $044^{\circ}$. The other fault trend expressed at this Snake Creek branch is continuous from the Bruneau Creek area (Fig. 14) and is manifested by fold geometry in footwall JS. Whereas fold axes in the hanging wall are parallel to the NE-trending fault northeast of Snake Creek, ENE-trending fold axes in footwall JS are subparallel to the fault spanning west to Bruneau Creek.

In the footwall, near-continuous exposure of Jacobsville Sandstone is deformed into a single asymmetric syncline with horizontal beds away from the PLV-JS contact steepening to vertical and overturned near the contact. Using measured changes in bedding orientation and distance along nearly continuous outcrop at Snake Creek, thickness of exposed Jacobsville section was calculated to be $130 \mathrm{~m}$. The muddy, conglomeratic, basal Jacobsville unit was not found in outcrop at this location; however, it has been observed in close proximity to the Keweenaw fault at Bruneau Creek and other areas to the northeast. 

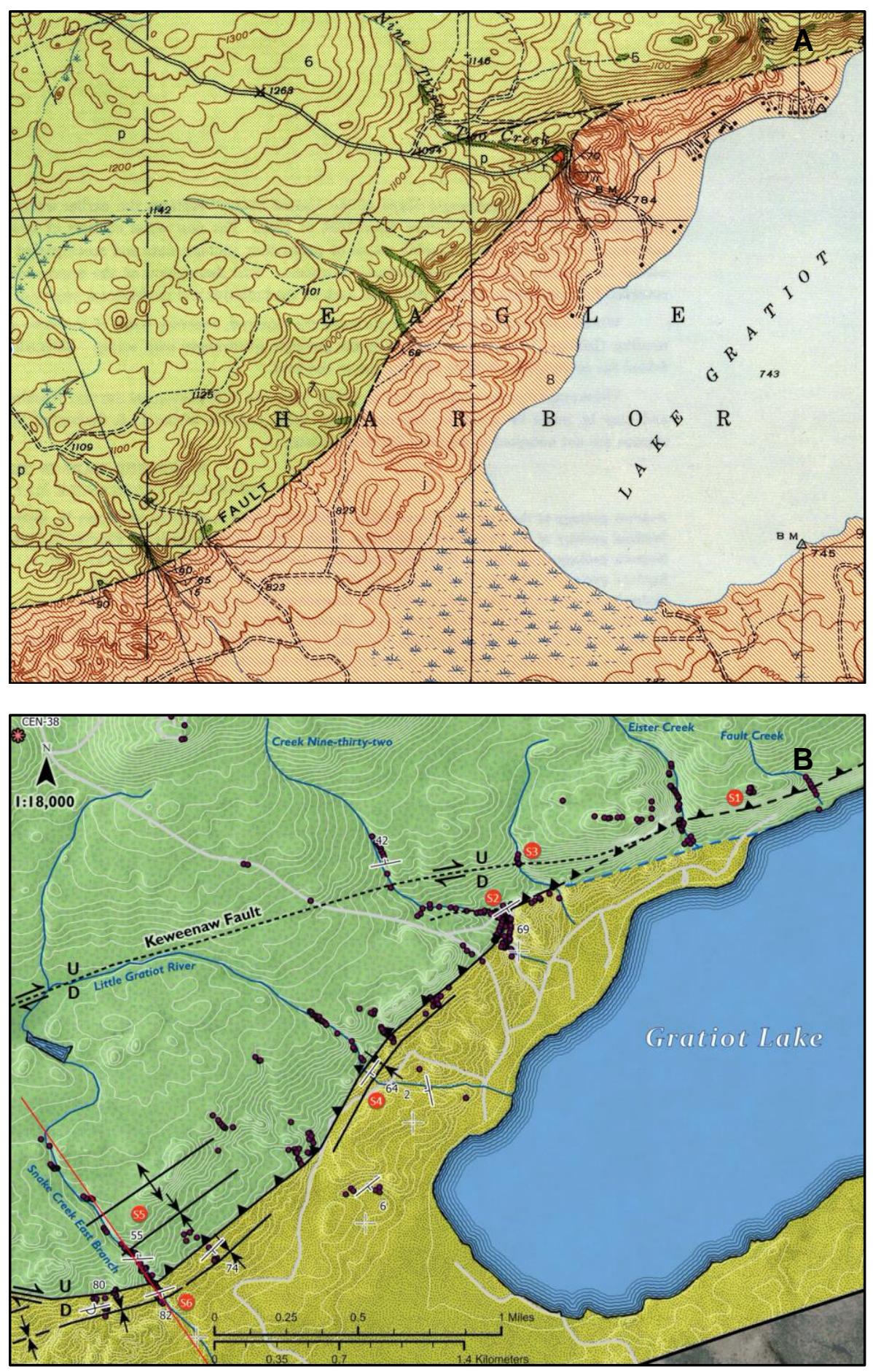

Figure 16: A: Published USGS bedrock geology map for area 2 near Snake Creek (Wright and Cornwall, 1954). B. New bedrock geology map showing different fault segments and outcrop data points as black dots. Opposing arrows indicate sense of strike slip on faults; letters " $U$ " and " $D$ " denote relative upward and downward dip slip. 


\section{Structural Analysis and Interpretation}

To quantify local and regional deformation, structural analyses of stratal orientations and fault slip lineations were performed to characterize fold geometry, to constrain crosssections along Bruneau Creek and the east tributary of Snake Creek, and to estimate principal strain axes at the time of fault slip. Bedding data are from outcrops along and near Bruneau Creek and the Snake Creek tributary, whereas fault slip data are from the entire mapped area west of Lake Gratiot. At both creek locations where cross-sections were constructed, bedding orientation data from hanging-wall PLV strata were analyzed separately from such data measured in footwall JS due to observed differences in fold geometry across the fault. At both locations, orientation data of JS bedding is more abundant and reliable than such data from PLV strata due to the ease of finding and measuring bedding surfaces in siliciclastic strata relative to sequences of lava flows.

\subsection{Bruneau Creek Transect}

Stratal orientations measured along Bruneau Creek in both the hanging-wall and footwall of the excavated fault within the Portage Lake Volcanics show significant differences in average strike, variability, and abundance (Fig. 17). It is generally difficult to measure stratal orientation with high-confidence in deformed volcanic environments, however the small dataset here is of good quality. Two groups of internally consistent data are identified in the figure below and represented with planes and associated poles: 1) data from the hanging-wall of the excavated fault $(\mathrm{N}=3$, pink), and 2) data from the footwall of the fault ( $\mathrm{N}=3$, yellow). Group 1 measurements are from mostly intact ophitic lava flows, while 
group 2 measurements are from brecciated, steeply-dipping, PLV strata probably deformed along a fault zone marked by the fault observed in outcrop. A best-fit line through bedding poles (Fig. 17, black arc) defines an anticlinal fold $\left(\mathrm{P} / \mathrm{A}=09^{\circ} / 186^{\circ} \mathrm{S}\right)$ trending parallel to the nearby mapped PLV-JS contact. The fold axial plane is oriented at $180^{\circ} / 57^{\circ} \mathrm{W}$ with an acute interlimb angle of $54^{\circ}$. This fold trends nearly parallel both to the excavated fault $\left(\mathrm{S} / \mathrm{D}=185^{\circ} / 32^{\circ} \mathrm{W}\right)$ and to the local PLV-JS contact trend (Fig. 14). The parallelism between the fold axis, excavated fault, and mapped PLV-JS contact defines a strong northerly structural grain, suggesting that fold deformation here is a byproduct of adjacent faulting. 


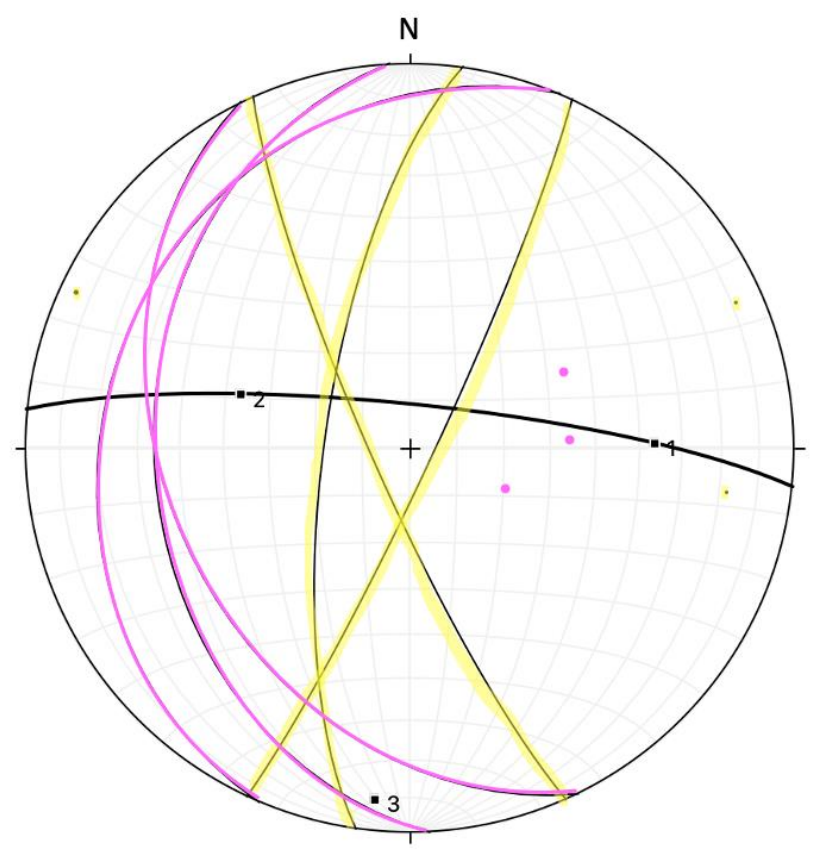

\section{Bruneau Creek: PLV Fold Axis: $186^{\circ} / 09^{\circ} \mathrm{S}$ Axial Plane: $180^{\circ} / 57^{\circ} \mathrm{W}$}

Figure 17: Equal-area stereonet plot and analysis of PLV stratal orientations; $N=6$, located west of the PLV-JS contact at Bruneau Creek. Two subsets are defined: group 1 (pink) and group 2 (yellow). Black arc is a best-fit line to bedding poles.

Stratal orientations measured in JS along Bruneau Creek define three groups (Fig. 18): 1) a dominant group $(\mathrm{N}=21)$ with $\mathrm{NE}$ trend that characterizes the main fold pattern; 2) a secondary group $(\mathrm{N}=3)$ with NNE trend likely defining a local minor fold; and 3) a single outlier with NNW trend that was excluded from subsequent calculations. In the field, these measurements define a tight fold sequence with five axial surfaces that trend generally to the northeast (Fig. 14). Analysis of Group 1 data (Fig. 18) defines the main JS fold pattern here that was used to guide cross-section construction. The main fold set in JS at Bruneau Creek has a composite axis plunging $1^{\circ}$ at $\mathrm{Az}=051^{\circ}$, and a corresponding axial plane with $\mathrm{S} / \mathrm{D}=051^{\circ} / 84^{\circ} \mathrm{S}$. The computed fold axis and axial plane are composite estimates because they average data from the entire fold set that decreases in tightness from northwest to 
southeast away from the PLV/JS contact. Analysis of Group 2 data (Fig. 20) define a secondary fold whose axis plunges $22^{\circ}$ at $\mathrm{Az}=25^{\circ}$ and whose axial plane has $\mathrm{S} / \mathrm{D}=$ $205^{\circ} / 80^{\circ} \mathrm{W}$. The fold axis of Group 2 trends $26^{\circ}$ counterclockwise to the composite fold axis of Group 1 and, together, groups 1 and 2 folding define a fan-like pattern that cuts the corner between the two main faults in this area (Fig. 14).

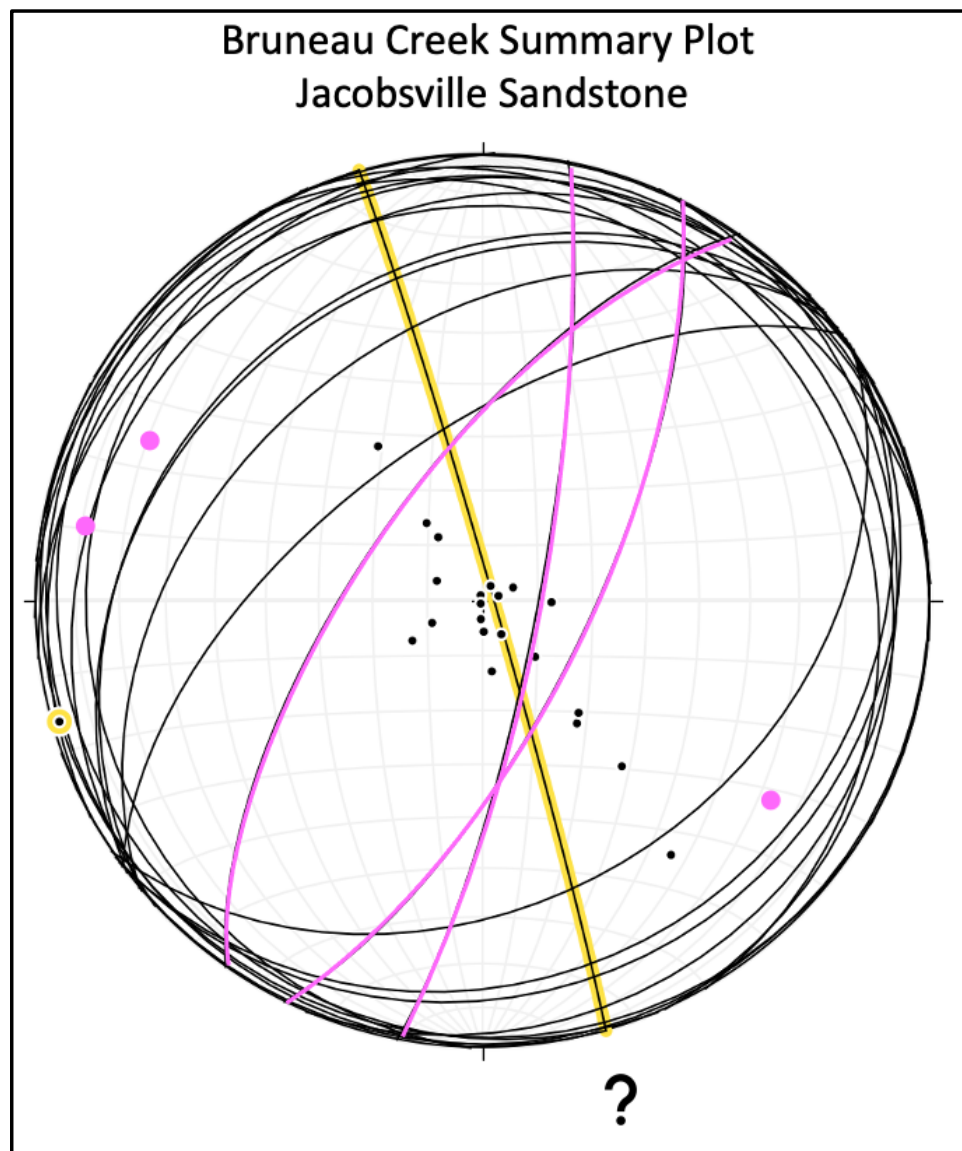

Figure 18: Equal-area stereonet plot and initial analysis of JS stratal orientations at Bruneau Creek east of the PLV-JS contact. Group 1 (black; $\mathrm{N}=21$ ) is dominant and considered characteristic of first-order folding. Group 2 (pink; N=3) is second-order and considered to represent minor local folding. Group 3 (yellow) is a single outlier excluded from further analysis. 


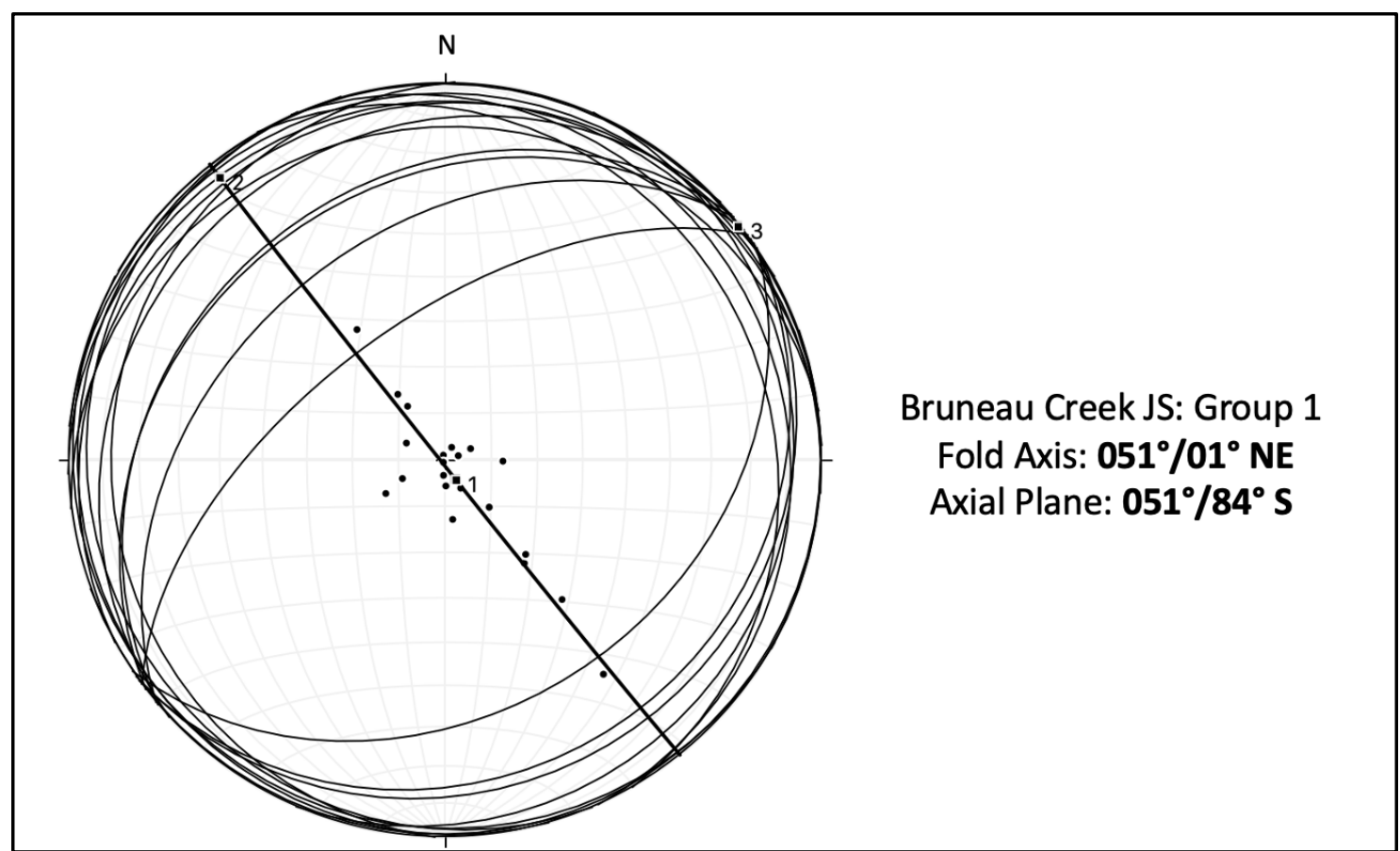

Figure 19: Equal-area stereonet analysis of Group $1(\mathrm{~N}=21)$ JS stratal orientations at Bruneau Creek, representing a composite fold analysis. This dominant group is considered characteristic of first-order folding.

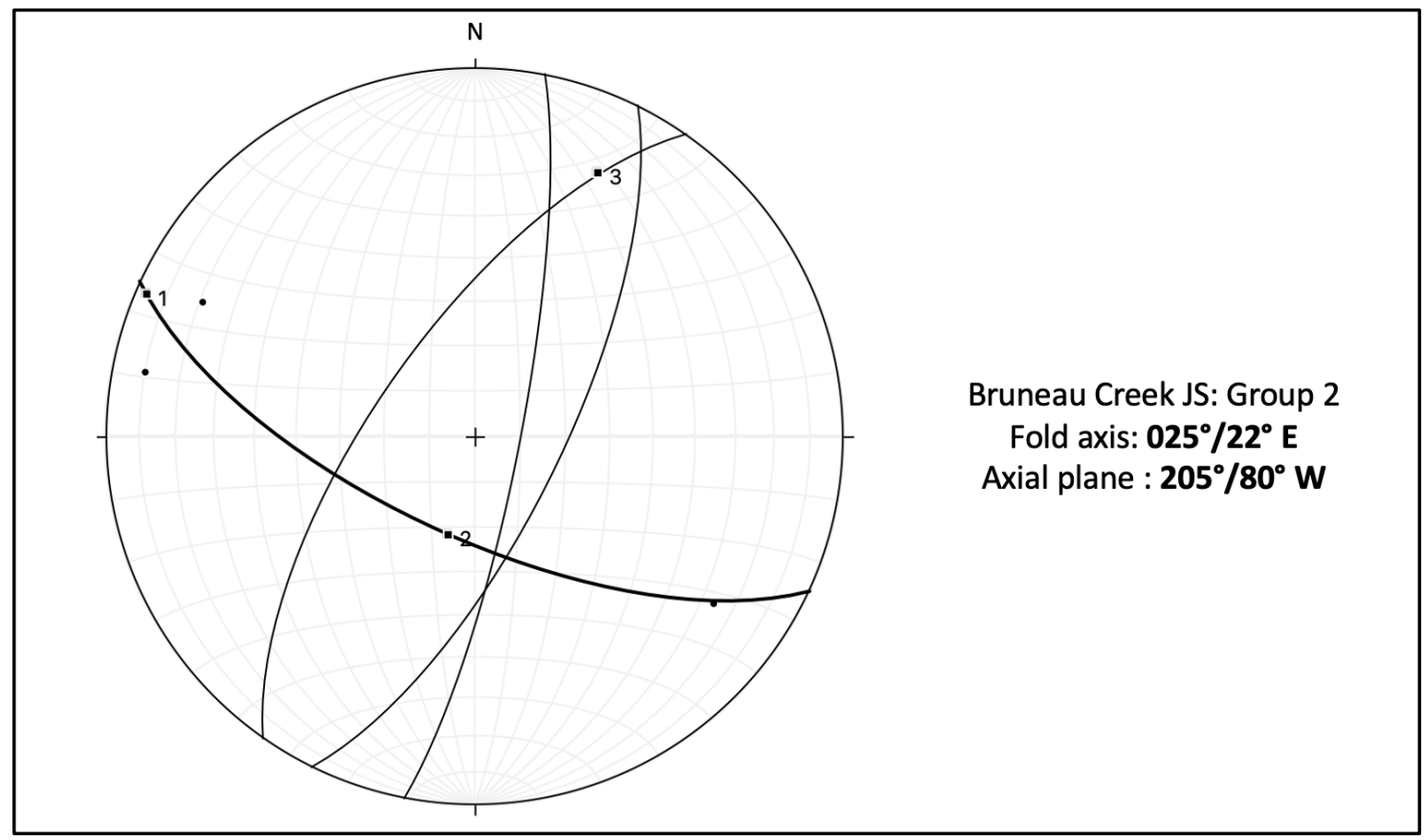

Figure 20: Equal-area stereonet plot analysis of Group $2(\mathrm{~N}=3)$ JS stratal orientations at Bruneau Creek. These values are from adjacent field sites and represent a secondary fold. 
Mapping along Bruneau Creek and related stereonet analyses reveal anticlinal deformation of PLV strata in the hanging-wall that is associated with a major, west-dipping, thrust fault or fault zone. The calculated anticlinal axis is nearly parallel to the fault excavated and measured during fieldwork and to the main PLV/JS contact to the east, which was not directly observed. The north-south structural orientation in hanging-wall PLV strata differs from the northeast-southwest trend of fold axes in footwall JS strata. The intensity of JS folding decreases away from the inferred PLV-JS contact as defined by an overall decrease in stratal dip and in tightness of folds. Thus, the fault excavated during fieldwork is interpreted as a thrust fault that overrode and folded JS toward the east.

Hanging-wall thrusting along the interpreted western fault is kinematically consistent with mostly strike-slip movement along the northern PLV-JS fault boundary. The combination of forces from motion on the intersecting faults could have caused the intense JS folding that decreases in tightness and whose axes rotate clockwise going southeast away from the fault intersection.

These results and interpretations are represented in a geologic cross section oriented normal to the north-trending PLV-JS contact at Bruneau Creek (Fig. 21). The elevation profile in the cross-section was created in ArcGIS, major contacts and structures were located along this profile, and dips of strata, faults, and fold axial surfaces were converted to apparent dips to accurately constrain the cross section. A JS thickness of $180 \mathrm{~m}$ used to create the cross section is larger than the 130-m JS thickness calculated at Snake Creek in order to have enough space to fit the tight JS folds between the erosional surface and underlying PLV strata. A basal Jacobsville unit consisting of a muddy conglomerate atop the PLV-JS 
unconformity is assumed to deform ductility based on its recessive character in outcrop and is likely to have facilitated the intense JS folding. The thrust zone, located in between the two fault lines, represents a broken, disconnected section of steeply dipping PLV blocks produced during thrust movement. 


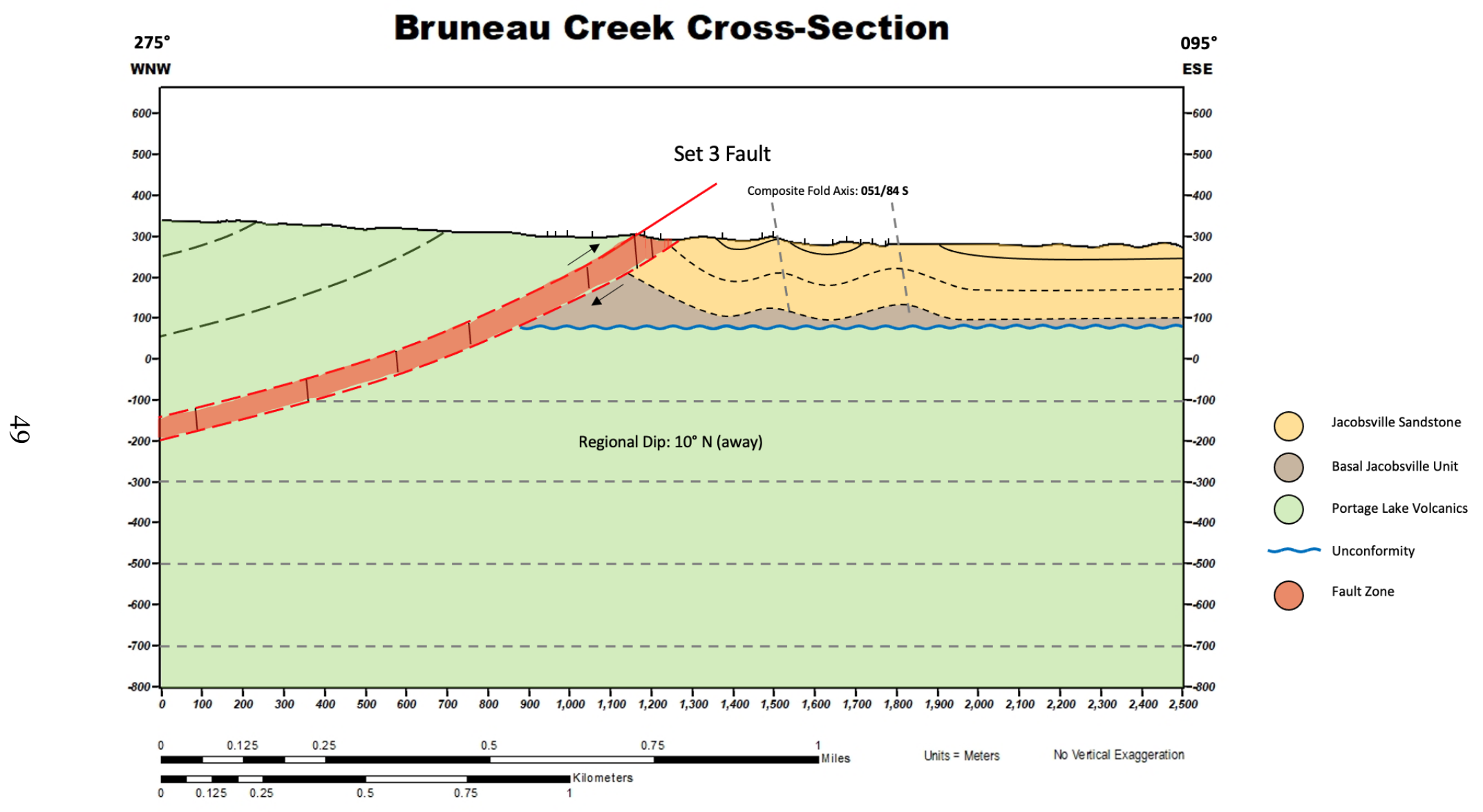

Figure 21: Geologic cross-section at Bruneau Creek drawn normal to the main Set 3 fault trend in the area. Regional dip in this area is $10^{\circ}$ away from the viewer. Vertical ticks on topographic surface represent individual station numbers. Fold axial surface is drawn to represent apparent dip. 


\subsection{Snake Creek Transect}

The east branch of Snake Creek crosses the intersection of two faults, one being the easterly extension of the Set 2 fault at Bruneau Creek and the other being a NE-trending Set 3 fault that intersects the main Keweenaw fault north of Lake Gratiot (Fig. 15). The fault geometry here defines an outside corner of hanging-wall PLV strata in contrast to the inside corner geometry defined by the fault intersection at Bruneau Creek. Upstream along Snake Creek, hanging-wall PLV strata including interflow sedimentary units define an anticline-syncline pair. Small faults and intense fracturing are observed in the hanging-wall but no major fault was discovered or inferred.

Analysis of stratal orientations from five PLV hanging-wall sites define a synclinal fold axis plunging $23^{\circ}$ at $044^{\circ} \mathrm{NE}$ and an axial plane with S/D of $025^{\circ} / 53^{\circ} \mathrm{E}$ (Fig. 22). Although the number of data points is small, this result is reliable because of the high quality of data from sedimentary layers that, in one case, could be traced through the synclinal trough. The computed fold trend is nearly parallel to the strike of the PLV-JS contact heading northeast from Snake Creek toward the intersection with the Keweenaw fault (Fig. 15). This PLVJS contact is well constrained by outcrops and inferred to be an east-verging thrust, analogous to the Bruneau Creek thrust, because of steep southeast tilting of JS strata in the

footwall and intense fracturing of PLV strata in the hanging-wall. Thus, the hanging-wall folds upstream along the Snake Creek east branch probably are related to mostly reverse movement of the eastern fault contact. 


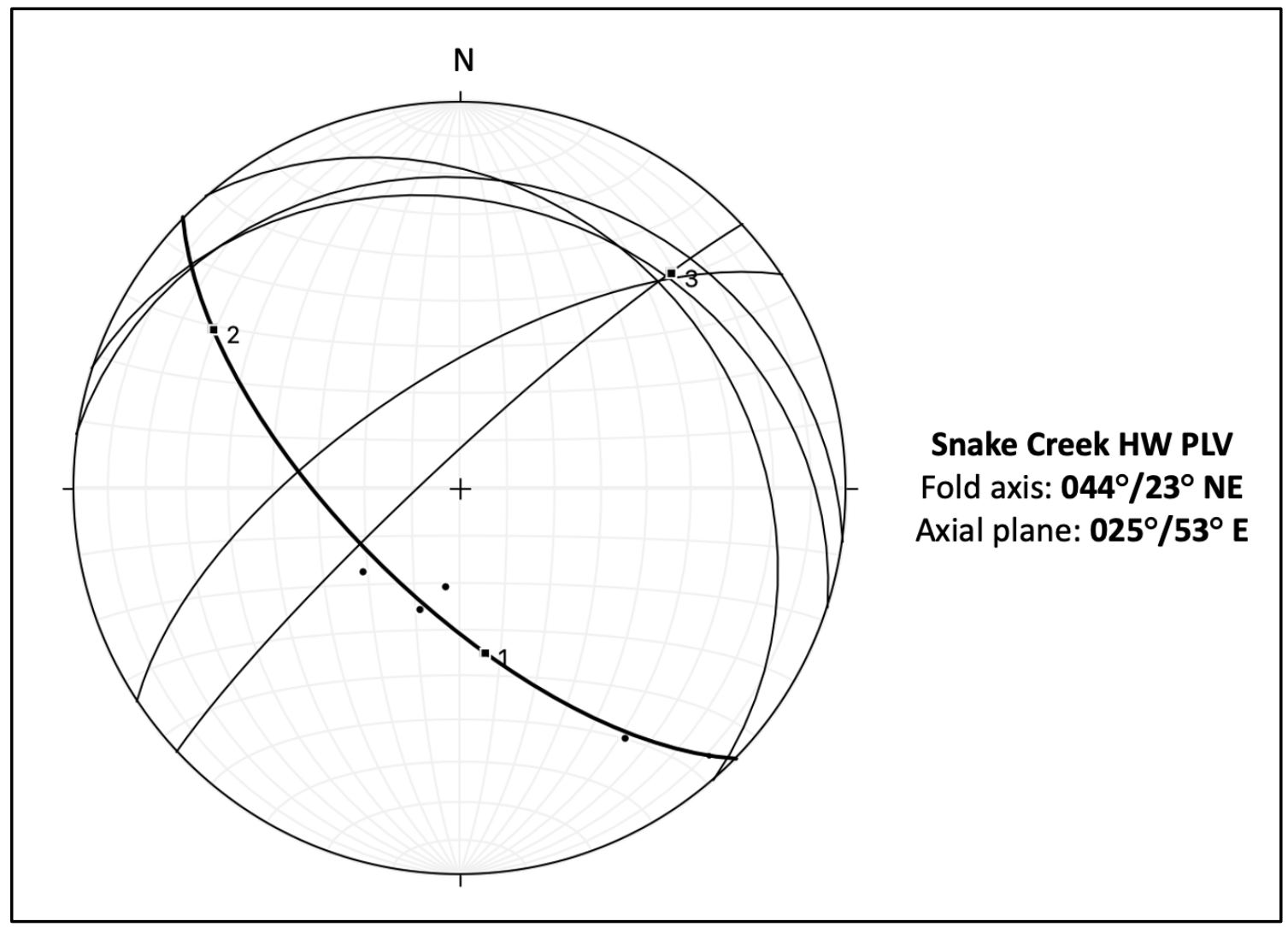

Figure 22: Equal-area stereonet plot of site-averaged PLV bedding data in the fault hanging-wall along the east branch of Snake Creek $(\mathrm{N}=5)$.

Stratal orientations measured in footwall Jacobsville Sandstone are from exposures along Snake Creek east branch as well as in adjacent drainages to the northeast and southwest. The highlighted data have a trend generally consistent with a regional WNW shortening direction, but they do not represent the syncline observed directly on Snake Creek. Therefore, these three data points were assigned to a second group and treated separately. 


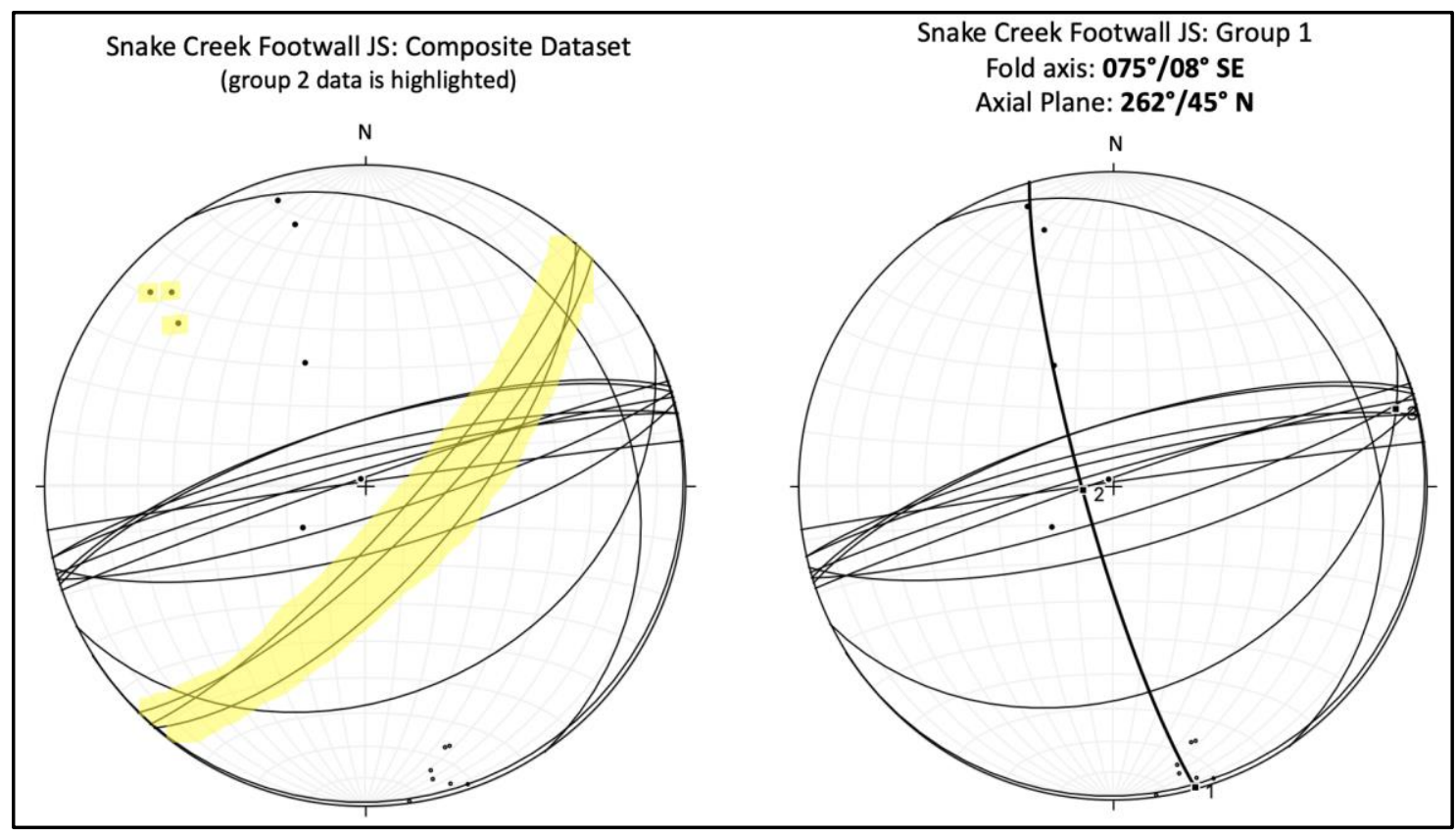

Figure 23: Equal-area stereonet plot of site-averaged JS bedding orientations along Snake Creek tributary and adjacent areas (left); bedding orientations excluding group 2 data from an adjacent drainage to the northwest (right). Group 1 data were used to calculate FW fold geometry at Snake Creek tributary.

Stereonet analysis of Group 1 stratal orientations from footwall JS define a syncline whose axis plunges $08^{\circ}$ at $075^{\circ}$ azimuth and whose axial surface strikes $\mathrm{N} 75^{\circ} \mathrm{E}$ and $\operatorname{dips} 45^{\circ} \mathrm{N}$ (Fig. 23). This footwall fold plunges in a direction approximately $30^{\circ}$ clockwise from the hanging-wall folds, suggesting that footwall and hanging-wall folding here result from differences in slip along the mostly strike-slip Set 2 fault from the west and the mostly dipslip Set 3 fault to the northeast. The simple asymmetric syncline in footwall JS at Snake Creek is similar to folds elsewhere within JS along set 1 faults and especially along set 2 faults in the current project area and the previous EdMap project (Fig. 3, DeGraff et al., 2018). Thus, the footwall syncline likely results from a component of north-side-up 
movement along the steeply dipping, mostly strike-slip, Set 2 fault entering the Snake Creek east branch from the Bruneau Creek area (Fig. 15).

The mapping results, stereonet analyses, and concepts just explained were used to construct a new geologic cross-section for this area (Fig. 24) that differs significantly from a nearby previously published section. The new cross section uses a revised Jacobsville thickness of $\sim 130 \mathrm{~m}$, as previously explained. A basal unit of muddy conglomerate with uncertain but limited thickness has been drawn below the sandstone-dominated sequence. Although this muddy conglomerate was not witnessed in outcrop at Snake Creek, it has been observed at or near the base of Jacobsville at Bruneau Creek and in other locations northeast and east of Snake Creek. The regional dip of PLV in the fault's footwall is assumed to be $10^{\circ} \mathrm{N}$ based on regional dip values for Keweenawan lava flows elsewhere around the edges of the Midcontinent Rift System (Cannon and Nicholson, 2001). Dip of PLV strata in the hanging wall northwest of our field sites is adopted from the USGS Bruneau Creek bedrock geology map (Wright and Cornwall, 1954). As for the Bruneau Creek cross-section, all dip values have been converted to apparent dip values before using them in building the Snake Creek cross-section (Fig. 24). 


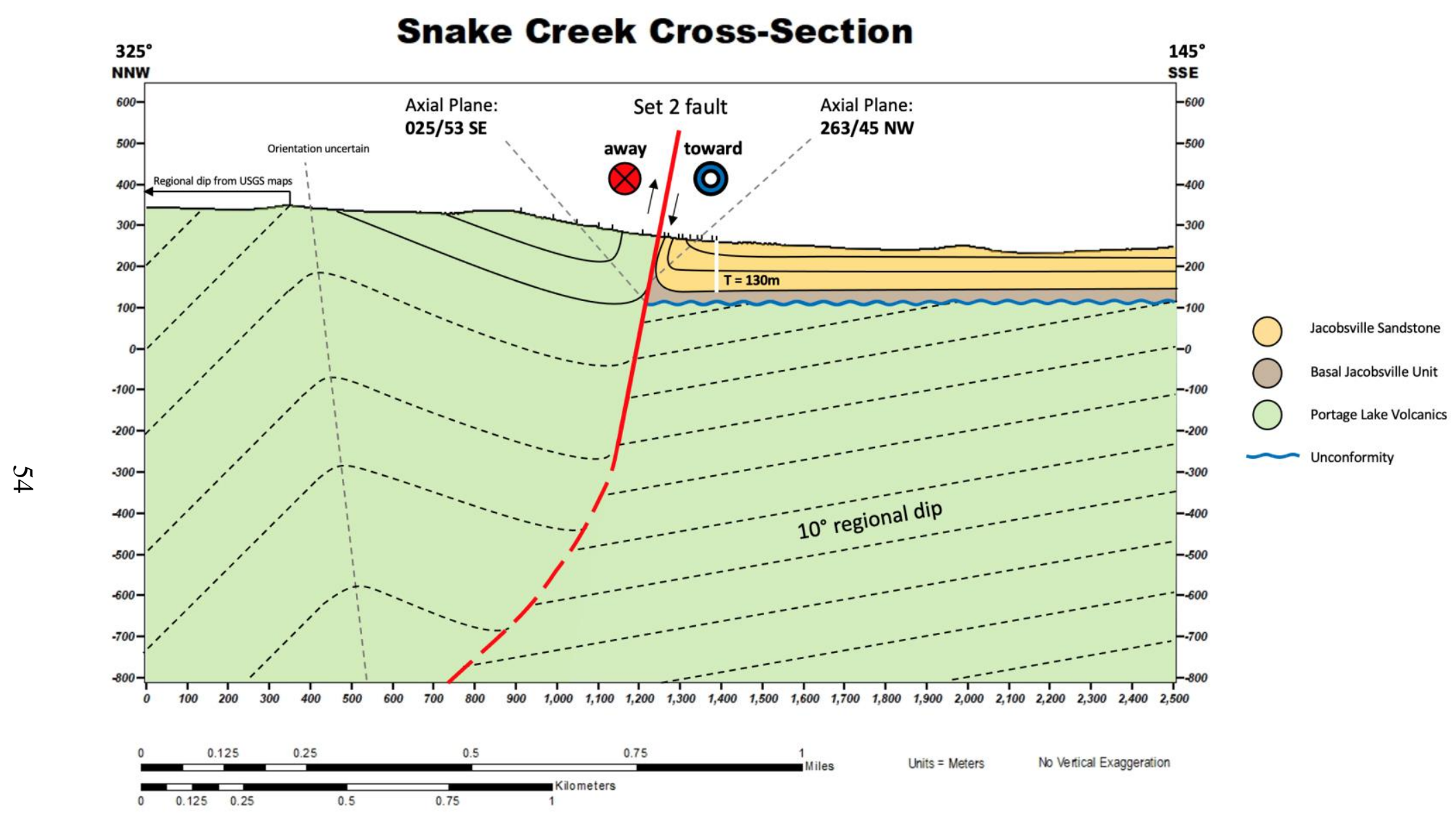

Figure 24: Geologic cross-section along the east branch of Snake Creek. Vertical ticks on topographic surface are field site locations. Fold axes are drawn to reflect apparent dip. Stratal dip at the NNW end of the cross section is adapted from the USGS map of the area. 


\subsection{Fault Slip Characteristics and Kinematic Analysis}

Parallel lineations on a fault surface that form by gouging, scraping, scratching, and mineralization during slip define the slip direction of the fault (Billings et al., 1972; Burg 2020; Fig. 25). Systematic asymmetric steps with long axes roughly perpendicular to such slip lineations define the sense of slip relative to a fault's strike line (Allison 2020; Fig. 26). Rake of a surface lineation is the angle between a strike line and the lineation (Fig. 27). In the project area, slip lineations were found on many fault surfaces within Portage Lake Volcanics, but were not uniformly distributed. Asymmetric steps were not always found with slip lineations, so sense of slip was determined less frequently than slip direction.

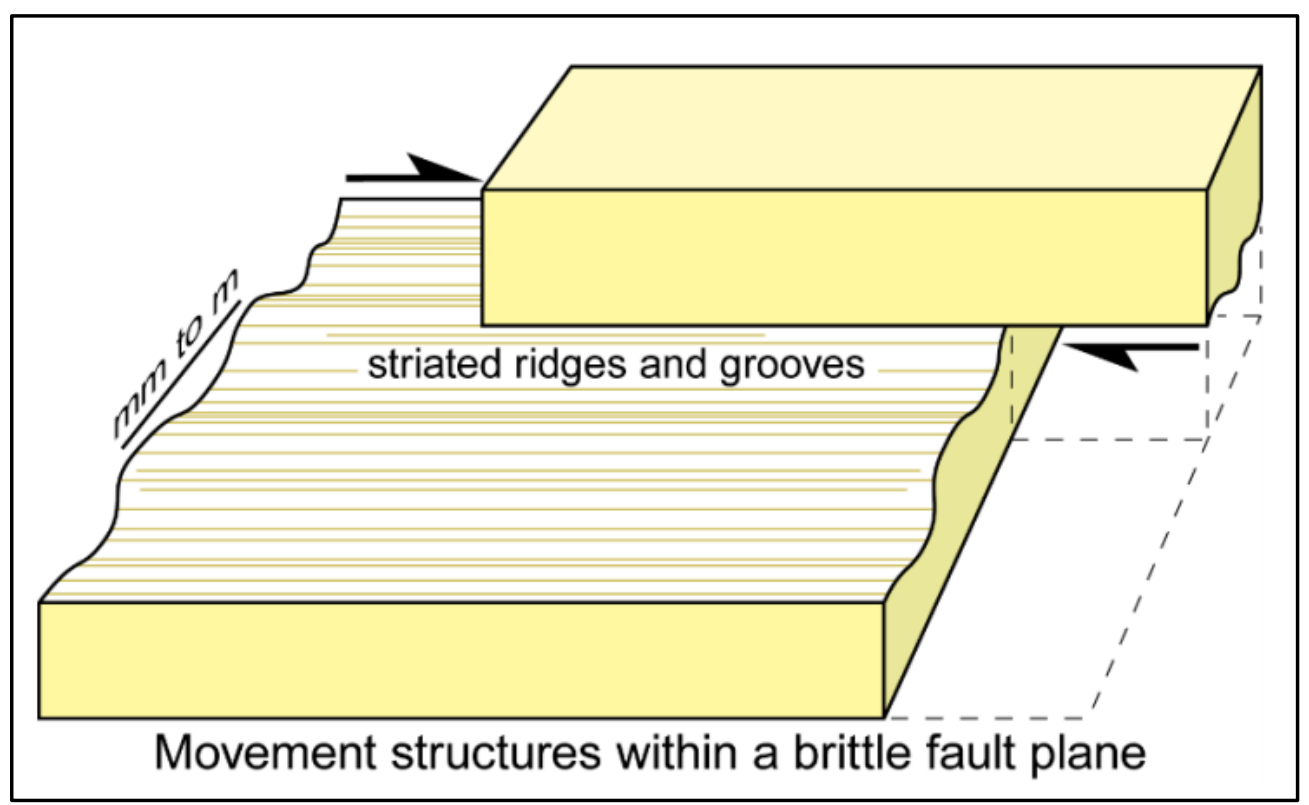

Figure 25: Lineations formed parallel to the slip vector (Burg 2020). 


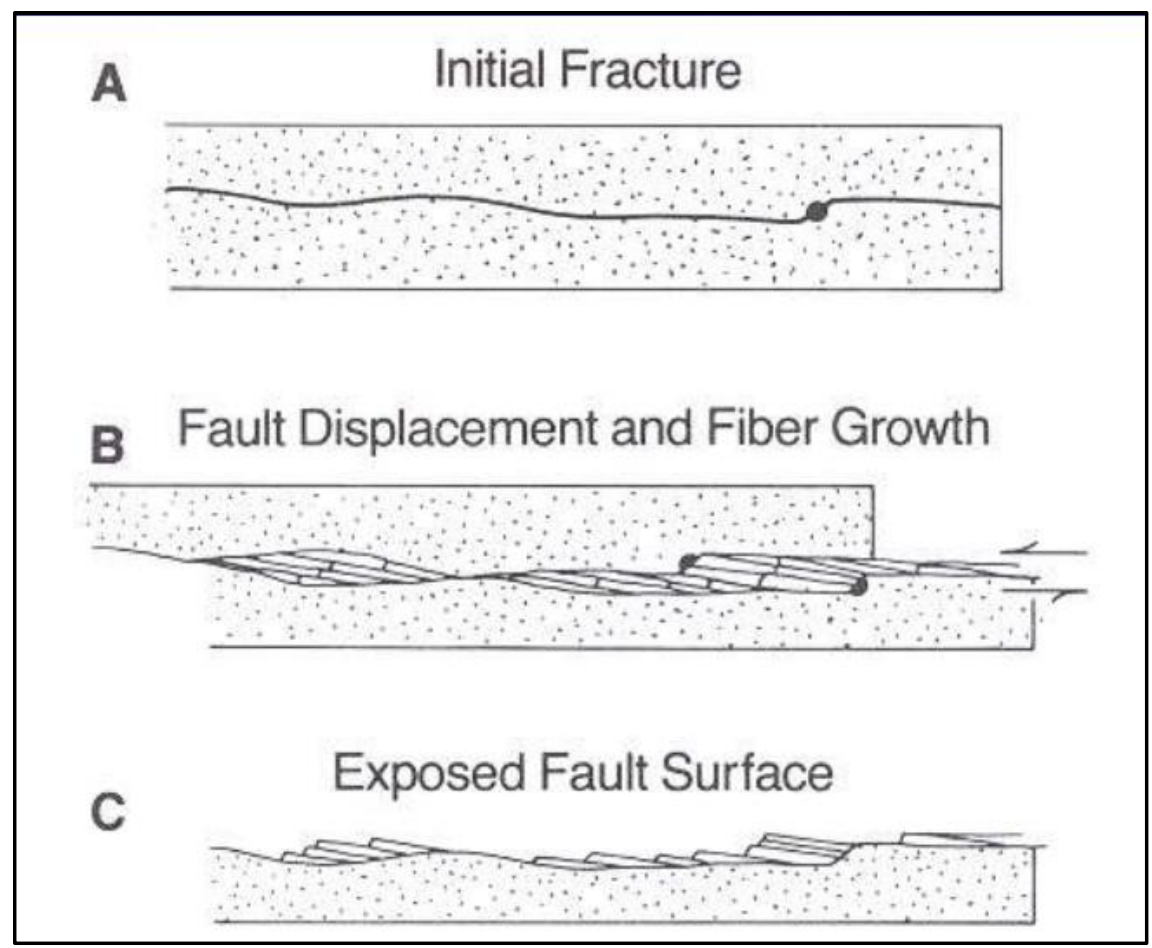

Figure 26: Asymmetric step formation on a fault surface and relationship to slip sense (Allison 2020).

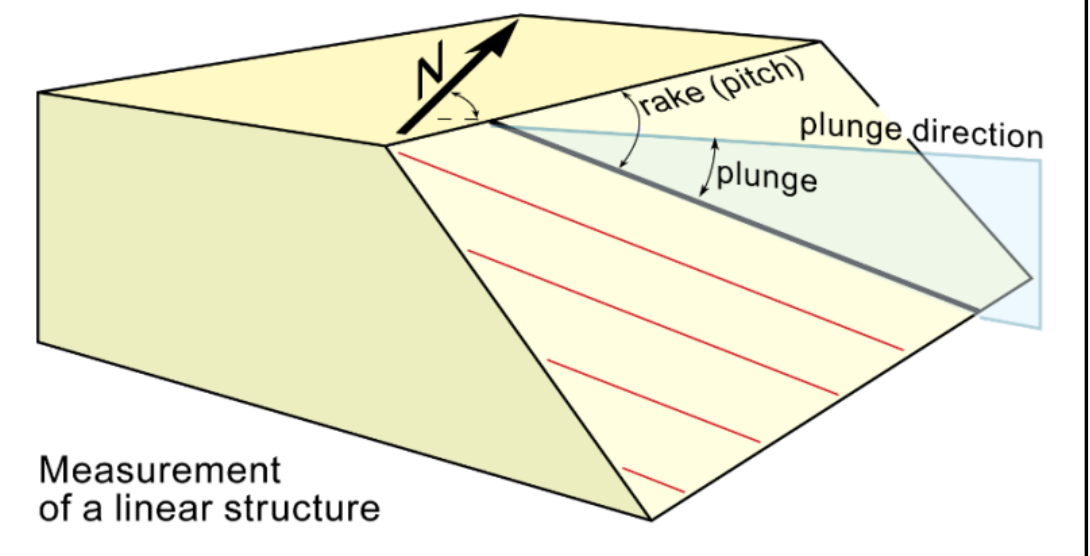

Figure 27: Rake and plunge of lineations on a planar surface (Burg, 2020).

Measured apparent rake values were converted to true rake in Excel and then analyzed to characterize fault motion within the project area. Rake is measured relative to a surface's strike line, so pure strike-slip motion has slip lineations with a rake of $0^{\circ}$, and pure dip-slip 
motion has a rake of $90^{\circ}$. In order to visualize the dataset and characterize overall movement along the Keweenaw fault system, a radial histogram of all rake values for the study area was created using Stereonet (Allmendinger, 2020; Fig. 28). The radial histogram of rake was created by using $10^{\circ}$ counting bins and without regard to whether rake was toward the left or right while viewing a fault surface. Rake values less than $45^{\circ}$ have a greater component of strike slip than dip slip, and vice versa. The histogram shows that rake of fault-slip lineations is skewed toward smaller values, indicating a dominant component of strike-slip movement within the project area. The arithmetic average rake of the entire dataset is $22^{\circ}$ and the mode (25\%) lies between $011^{\circ}$ and $20^{\circ}$ from the strike line. The arithmetic mean slip vector can be resolved into horizontal (strike-slip) and vertical (dip-slip) components to determine average slip characteristics of the Keweenaw fault system. This trigonometry calculation gives a strike-to-dip slip ratio of $2.5: 1$, indicating a far greater strike-slip movement within the fault system than dip-slip movement. 


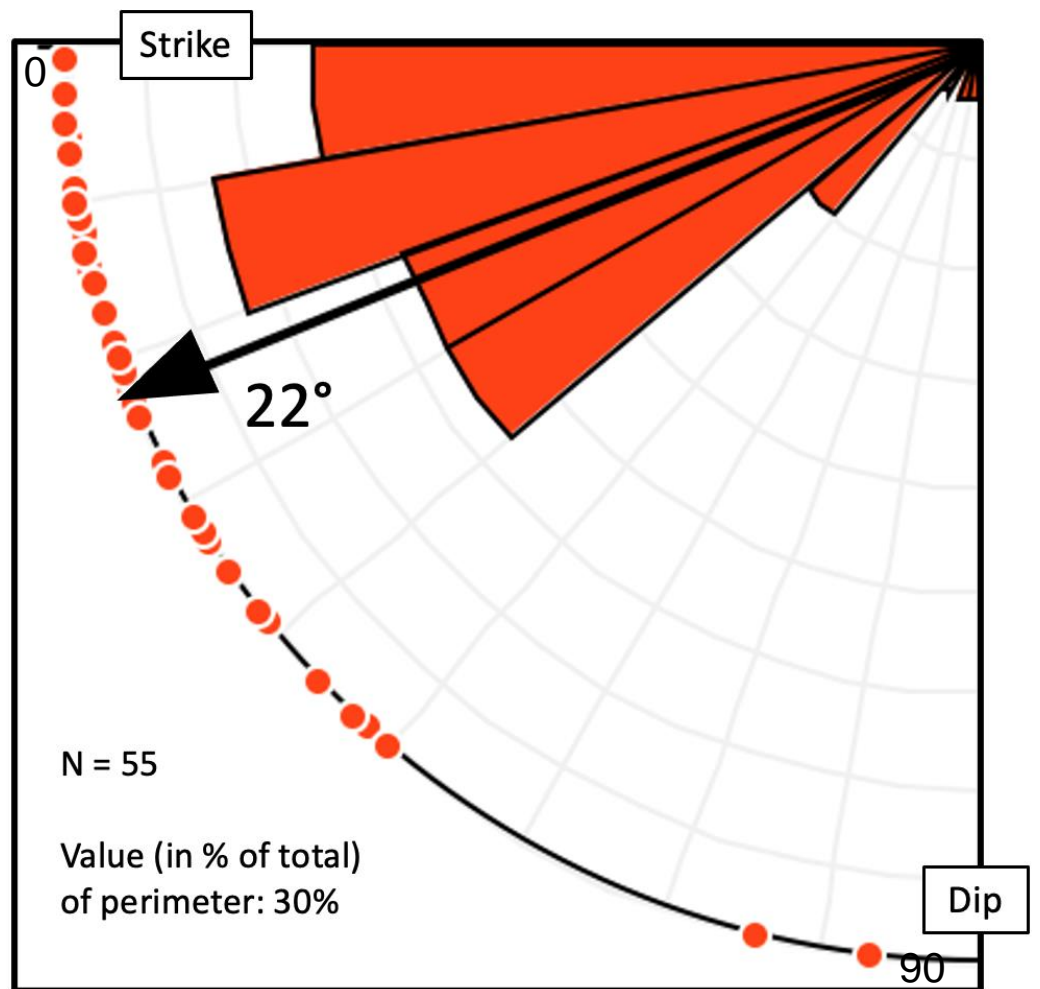

Figure 28: Radial histogram of fault lineation rakes counted in $10^{\circ}$ bins. Black arrow denotes arithmetic mean of data. $25 \%$ of data resides within the largest slice. Strike-slip corresponds to rake $=0^{\circ}$; dip-slip corresponds to rake $=90^{\circ}$. Red dots on perimeter are rake values that were counted within bins.

When fault-slip lineations are associated with steps that allow slip sense to be determined, these measurements can be used to estimate regional axes of paleostrain using fault-slip inversion analysis (Marrett and Allmendinger, 1990). The results of such analysis can then be used to make inferences about paleostress, assuming regional strain was non-rotational relative to stress, and about kinematics of the Keweenaw fault system. Fault-slip inversion uses measurements of fault orientation, slip direction, and slip sense to compare with predicted slip on faults with the same orientations and for various strain regimes. The strain regime that achieves the best fit of predicted to observed slip in a least-squares sense is the strain regime that likely existed when the fault system was active. Fault-slip inversion provides orientations of principal strain axes that represent greatest shortening $(\mathrm{P})$, greatest 
extension (T), and an intermediate strain axis normal to the other two. An underlying assumption is that individual slip measurements are indicative of maximum resolved regional shear stress (Pollard et al., 1993; Allmendinger, 2019; Fig. 29). Fault-slip inversion using project data and the FaultKin application yielded the following principal strain axes.

Axis 3: (P-axis; compressional)

Axis 1: (T-axis; strain)

Axis 2: (intermediate shortening)

\section{Trend}

$105^{\circ}$

$209^{\circ}$

$303^{\circ}$

\section{Plunge}

$35^{\circ}$

$20^{\circ}$

$62^{\circ}$

The maximum shortening direction ( $\mathrm{P}$ axis) inferred from measured faults in this area has an azimuth of $105^{\circ}-285^{\circ}$ and the maximum extensional direction ( $\mathrm{T}$ axis) has an azimuth of $015^{\circ}-195^{\circ}$.

The application of this inferred paleostrain regime on the three fault trends in the area implies that: 1) ENE-trending Set 1 faults moved by a combination of right-lateral strike slip and reverse slip with north side up; 2) ESE-trending Set 2 faults moved mostly by right-lateral strike slip with lesser reverse slip than Set 1 faults; and 3) NNE-trending Set 3 faults moved mostly by reverse or thrust movement depending on dip angle. This inferred fault movement is consistent with inferences from fold orientations and fault characteristics, and it suggests an average slip behavior for the Keweenaw fault system that is primarily right-lateral strike-slip with lesser north-side-up reverse slip. 


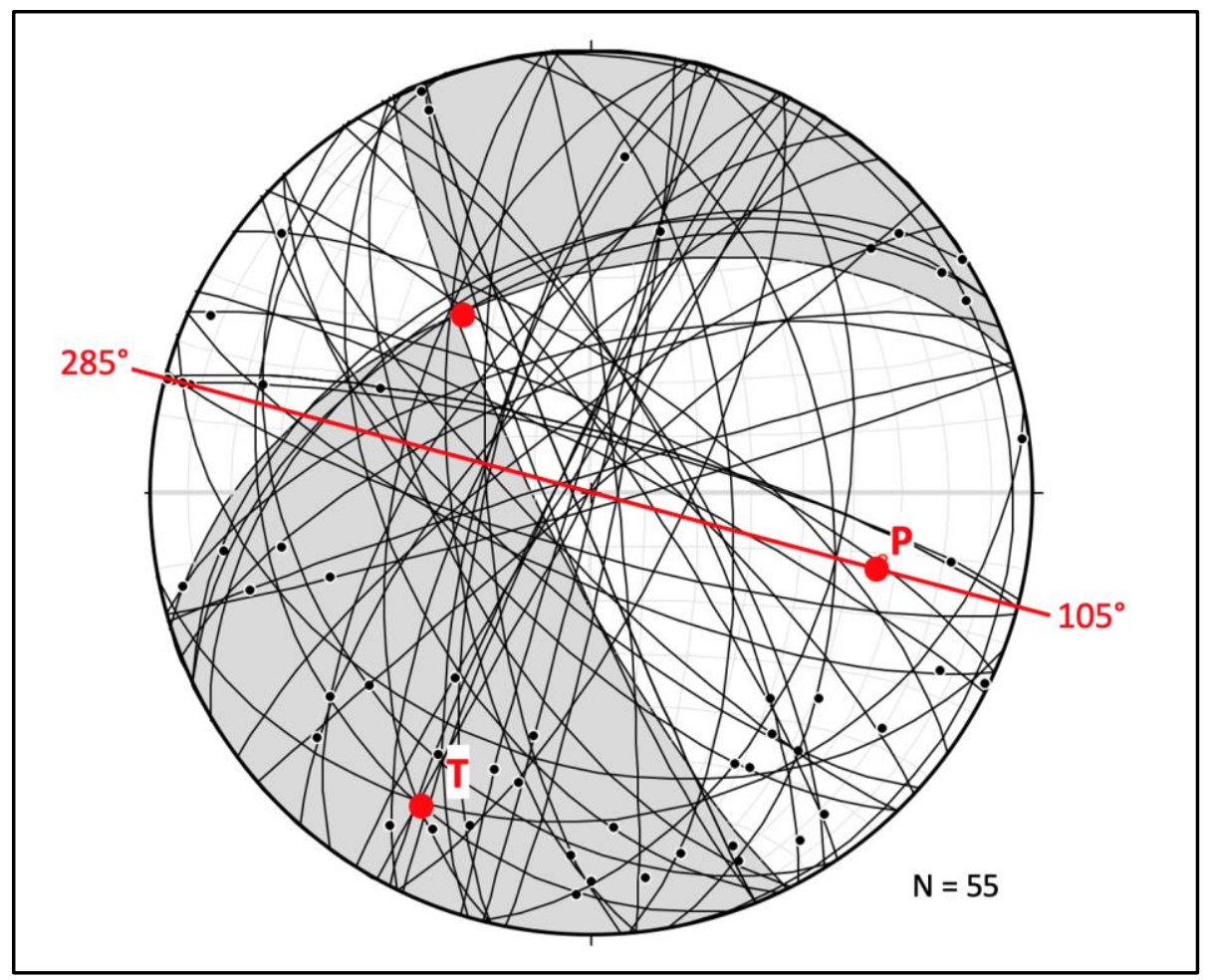

Figure 29: Linked Bingham, fault-plane-solution plot showing fault planes (arcs) and lineations (black dots on arcs), using sense of slip to compute principal strain axes. The principal shortening direction is along a line with azimuth $105^{\circ}-285^{\circ}$ (FaultKin from Allmendinger, 2019). 


\section{Discussion of Results and Significance}

The mapping results and structural analyses just presented are largely consistent with results of the previous 2017-2018 EdMap project that lies immediately east of the current project area (Fig. 3). Mapping in both EdMap project areas has revealed a complex, segmented, Keweenaw fault system rather than a continuous fault with a single trace as previously interpreted. The fault system in the current EdMap area comprises three main fault sets: 1) ENE-striking Set 1 faults with northerly dip and mixed strike and dip slip, 2) ESE-striking faults with steep northerly dip and dominant strike slip, and 3) NNE-striking faults striking with moderate-shallow westerly dip and dominant reverse slip. The three fault sets define blocks of PLV strata that have moved in an easterly direction along faults of the first two sets and have thrust over JS along faults of the third set. Folding of hangingwall and footwall strata is common near most faults and fold axes are subparallel to the faults, suggesting that folding is genetically related to fault movement. Fold characteristics vary among the fault sets, however, being more intense and having multiple axes adjacent to NNE-trending Set 3 faults and having simpler drape-style bending adjacent to Set 1 and 2 faults. The simple, well-exposed, drape fold in the footwall at Snake Creek east branch exposes an estimated $130 \mathrm{~m}$ of JS, which is significantly less than the $2-3 \mathrm{~km}$ of JS thickness near Houghton, MI.

Fault slip observations and analyses of both EdMap projects are very similar and support the idea of dominant strike-slip motion on the fault system (Fig. 30). Rake histograms generated from fault lineation measurements show this dominance of strike slip by the relatively low values of rake common in both areas. The arithmetic means for the two 
projects are within $4^{\circ}$ of each other, while the modes of each dataset are within $10^{\circ}$. These small differences are probably not significant because of differences in sample size between the two areas and the relatively small number of samples. The differences could result from the relative locations of the project areas along the gently curved path of the fault system, or from the more diffuse nature of the fault system in the current project area relative to the former, but neither scenario is clear at this time. In general, the region features a strike-slip to dip-slip component ratio of at least 2:1.

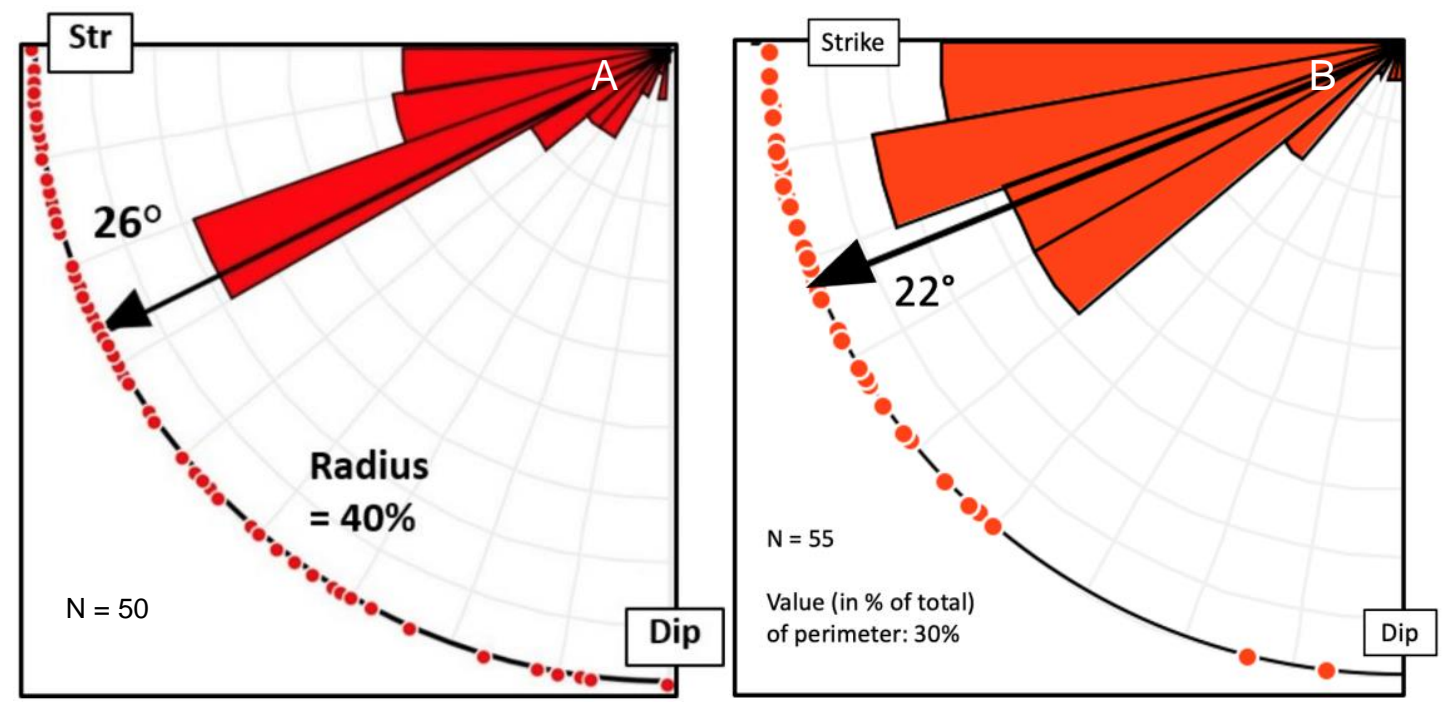

Figure 30: Radial histograms of fault lineation rakes A. 2017-2018 EdMap results (N = 50 B. 20192020 EdMap results for western part $(\mathrm{N}=55)$.

Fault-slip inversion results of both EdMap projects are also similar and provide consistent estimates of principal strain axes, but with some unexplained differences (Fig. 31). Both stereoplots feature axes of greatest shortening $(\mathrm{P})$ that are within $12^{\circ}$ of the other when projected onto a horizontal plane, and that have a general WNW-ESE orientation. Both stereoplots also have axes of greatest extension (T) oriented in the same general direction 
when projected on a horizontal plane, though one plunges NE while the other plunges SW. The main difference between the two stereoplots is the relative position of the $\mathrm{P}$ and intermediate strain axes, which are essentially reversed. Reasons for this reversal are unclear, though it may result from previously mentioned differences in sample size and relative positions along the Keweenaw fault system. Alternatively, these variations may be a product of a regional far-field strain superimposed onto fault systems with slightly different fault trends and internal arrangements.
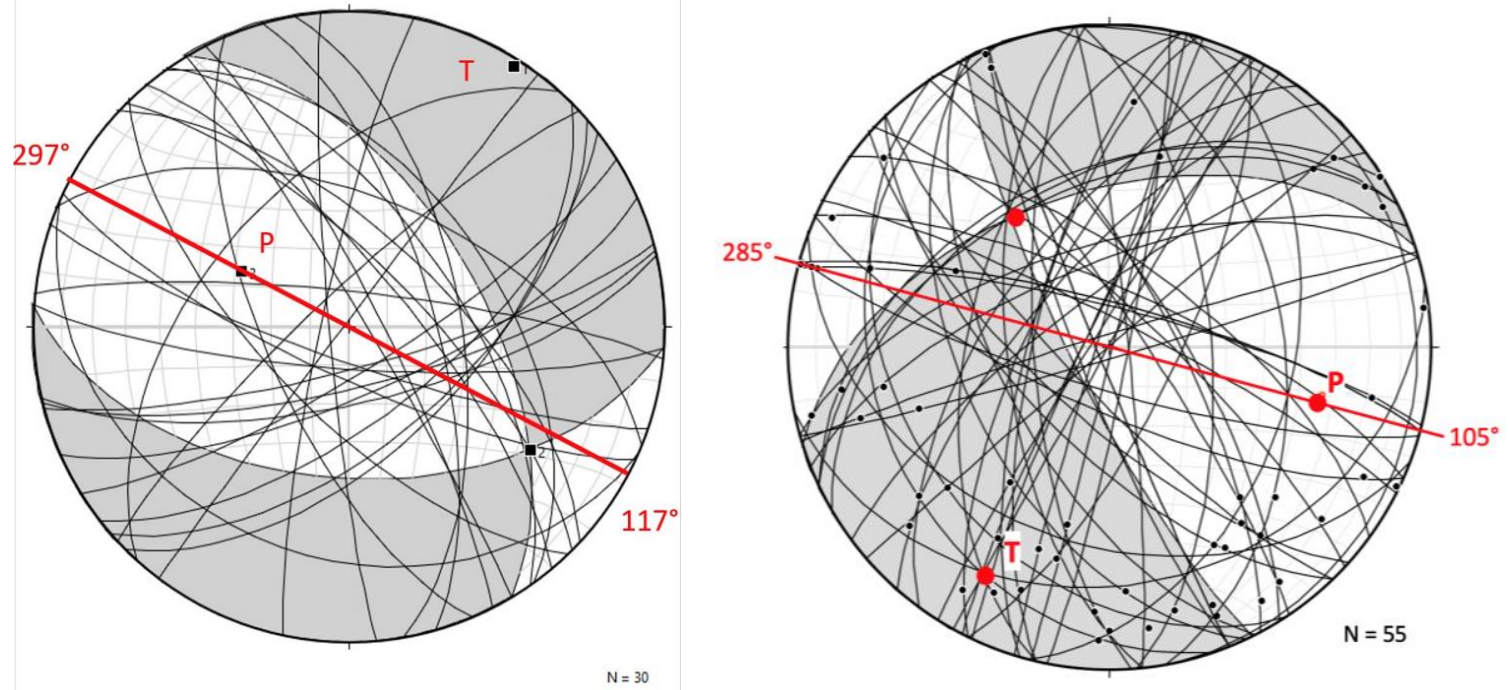

Figure 31: FaultKin plots of the first EdMap project (left) and second EdMap project (right) using fault planes, rake lineations, and sense of slip to compute three principal axes of strain.

Although some differences exist between results of the two EdMap projects, their overwhelmingly similar results strengthen the emerging understanding of the Keweenaw fault as a complex fault system with multiple sets of interconnected faults. Faults in both areas are primarily organized in an en echelon arrangement and have dominant right-lateral 
strike-slip movement and less reverse dip-slip movement. Folds in both project areas typically are subparallel to adjacent faults and are more common than previously thought. Both projects provide strong evidence that the Keweenaw fault system is an anastomosing, transpressional fault network with fault segments of different strike having differing ratios of strike slip to dip slip.

The long-held idea of the Keweenaw fault being a relatively simple thrust fault having a single trace and homoclinal dip in its hanging-wall is not consistent with recent highresolution mapping. Fault-slip observations and subsequent analyses indicate that thrusting is not the dominant mode of faulting along this portion of the Keweenaw fault system, as was previously thought. Additional mapping and data from the next segment of the fault system to the southwest would extend the new insights gained by the current work data and would undoubtably reveal new details about the complex structural framework of the Keweenaw Peninsula. 


\section{Conclusion}

Results from this project have revised understanding of the Keweenaw fault system by improving resolution of deformation geometry and providing insights about fault system kinematics. For decades, the consensus has been that the Keweenaw fault originated as a normal fault during rifting, was later inverted as a thrust fault by compressional forces, and now follows a single, continuous, curved trace locally associated with smaller faults. This thesis project has revealed that the Keweenaw fault is not a simple thrust fault as commonly described, but rather is a complex network of faults that likely evolved as a result of forces from various periods of tectonic activity. The new precision mapping, structural data and analyses presented here not only contribute to knowledge about the Keweenaw fault system - they largely reform the narrative. Findings of this thesis study, and the 2019-2020 EdMap project as a whole, support recent findings from detailed geologic mapping and structural analysis of the same fault system toward the east, thereby instilling confidence in those earlier results. Future studies of the same fault system to the southwest are critical to further our understanding of the Keweenaw fault system as a whole. I hope that these findings instill a renewed interest in the structural complexity of the Keweenaw Peninsula. 


\section{Reference List}

Allison, D. T., 2020, Structural Geology: University of South Alabama.

Bartholomew, M. J., and Hatcher Jr, R. D., 2010, The Grenville orogenic cycle of southern Laurentia: Unraveling sutures, rifts, and shear zones as potential piercing points for Amazonia: Journal of South American Earth Sciences, v. 29, no. 1, p. 4-20.

Billings, M. P., and Billings, M., 1972, Structural geology, Prentice-Hall Englewood Cliffs, New Jersey, v. 551.1 B5.

Bornhorst, T. J., Paces, J. B., Grant, N. K., Obradovich, J. D., and Huber, N. K., 1988, Age of native copper mineralization, Keweenaw Peninsula, Michigan: Economic Geology, v. 83, no. 3, p. 619-625.

Burg, J.-P., 2020, Faults Faults, ETH Zurich Department of Earth Sciences.

Butler, B. S., and Burbank, W. S., 1929, The copper deposits of Michigan, US Government Printing Office.

Cannon, W., McRae, M. E., and Nicholson, S., 1999, Geology and mineral deposits of the Keweenaw Peninsula and vicinity, Michigan: The Survey; USGS Information Services, distributor], 0607922990.

Cannon, W. F., 1994, Closing of the Midcontinent rift-A far-field effect of Grenvillian compression: Geology, v. 22, no. 2, p. 155-158.

Cannon, W. F., and Nicholson, S. W., 1992, Revisions of stratigraphic nomenclature within the Keweenawan Supergroup of northern Michigan, US Government Printing Office, v. 1969.

Craddock, J. P., Konstantinou, A., Vervoort, J. D., Wirth, K. R., Davidson, C., FinleyBlasi, L., Juda, N. A., and Walker, E., 2013, Detrital zircon provenance of the Mesoproterozoic Midcontinent Rift, Lake Superior region, USA: The Journal of Geology, v. 121, no. 1, p. 000-000.

Dallmeyer, R. D., Wright, J. E., SECOR JR, D. T., and Snoke, A. W., 1986, Character of the Alleghanian orogeny in the southern Appalachians: Part II. Geochronological constraints on the tectonothermal evolution of the eastern Piedmont in South Carolina: Geological Society of America Bulletin, v. 97, no. 11, p. 1329-1344.

Davis, D., and Paces, J., 1990, Time resolution of geologic events on the Keweenaw Peninsula and implications for development of the Midcontinent Rift system: Earth and Planetary Science Letters, v. 97, no. 1-2, p. 54-64. 
DeGraff, J. M., Carter, B. T., and Tyrrell, C. W., Keweenaw Fault Geometry and Kinematics North of Portage Lake, Michigan, in Proceedings GSA Annual Meeting in Indianapolis, Indiana, USA-20182018, GSA.

Gordon, M. B., and Hempton, M. R., 1986, Collision-induced rifting: the Grenville Orogeny and the Keweenawan rift of North America: Tectonophysics, v. 127, no. $1-2$, p. 1-25.

Green, J., Bornhorst, T., Chandler, V., Mudrey Jr, M., Meyers, P., Pesonen, L., and Wilband, J., 1987, Keweenawan dykes of the Lake Superior region: evidence for evolution of the Middle Proterozoic Midcontinent Rift of North America, Mafic dyke swarms, p. 289-302.

Hamblin, W. K., 1958, The Cambrian sandstones of northern Michigan, University of Michigan.

Hinze, W. J., Braile, L. W., and Chandler, V. W., 1990, A geophysical profile of the southern margin of the Midcontinent rift system in western Lake Superior: Tectonics, v. 9, no. 2, p. 303-310.

Hnat, J. S., Van der Pluijm, B. A., and Van der Voo, R., 2006, Primary curvature in the Mid-Continent Rift: Paleomagnetism of the Portage Lake Volcanics (northern Michigan, USA): Tectonophysics, v. 425, no. 1-4, p. 71-82.

Huber, N. K., 1973, Geologic map of Isle Royale National Park, Keweenaw County, Michigan: US Geological Survey.

Huber, N. K., 1973, The Portage Lake Volcanics (Middle Keweenawan) on Isle Royale, Michigan, 2330-7102.

Hutchinson, D., White, R., Cannon, W., and Schulz, K., 1990, Keweenaw hot spot: Geophysical evidence for a $1.1 \mathrm{Ga}$ mantle plume beneath the Midcontinent Rift System: Journal of Geophysical Research: Solid Earth, v. 95, no. B7, p. 1086910884.

Irving, R. D., and Chamberlin, T. C., 1885, Observations on the junction between the eastern sandstone and the keweenaw series on keweenaw point, Lake Superior, US Government Printing Office, v. 23.

Jirsa, M. A., 1984, RI-30 Interflow Sedimentary Rocks in the Keweenawan North Shore Volcanic Group, Northeastern Minnesota.

Kalliokoski, J., 1982, 7E Jacobsville sandstone: Memoir of the Geological Society of America, v. 156, p. 147. 
Kulakov, E., Department of Geological and Mining Engineering and Sciences, Michigan Technological University, 1400 Townsend Drive, Houghton, MI 49931. Directions: Leave downtown Houghton and head east on Montezuma avenue and College Avenue. Continue on US 41 south for 27 miles. In Baraga MI turn right and continue to follow M38 west for 13.5 miles. Make left turn on S Laird road and follow it for 5.7 .

Lane, A. C., 1903, Studies of the grain of igneous intrusives: Bulletin of the Geological Society of America, v. 14, no. 1, p. 369-384.

Malone, D. H., Stein, C. A., Craddock, J. P., Kley, J., Stein, S., and Malone, J. E., 2016, Maximum depositional age of the Neoproterozoic Jacobsville Sandstone, Michigan: Implications for the evolution of the Midcontinent Rift: Geosphere, v. 12, no. 4, p. 1271-1282.

Marrett, R., and Allmendinger, R. W., 1990, Kinematic analysis of fault-slip data: Journal of structural geology, v. 12, no. 8, p. 973-986.

Miller, J., Nicholson, S., Easton, R., Ripley, E., and Feinberg, J., 2013, Geology and mineral deposits of the $1.1 \mathrm{Ga}$ Midcontinent rift in the Lake Superior Region-an overview: Field guide to the copper-nickel-platinum group element deposits of the Lake Superior Region. Edited by Miller, J. Precambrian Research Center Guidebook, v. 13, no. 01, p. 1-49.

Nicholson, S. W., and Shirey, S. B., 1990, Midcontinent rift volcanism in the Lake Superior region: $\mathrm{Sr}, \mathrm{Nd}$, and $\mathrm{Pb}$ isotopic evidence for a mantle plume origin: Journal of Geophysical Research: Solid Earth, v. 95, no. B7, p. 10851-10868.

Pollard, D., Saltzer, S., and Rubin, A. M., 1993, Stress inversion methods: are they based on faulty assumptions?: Journal of Structural Geology, v. 15, no. 8, p. 1045-1054.

Spencer, C. J., Cawood, P. A., Hawkesworth, C. J., Prave, A. R., Roberts, N. M., Horstwood, M. S., and Whitehouse, M. J., 2015, Generation and preservation of continental crust in the Grenville Orogeny: Geoscience Frontiers, v. 6, no. 3, p. 357-372.

Stein, C. A., Kley, J., Stein, S., Hindle, D., and Keller, G. R., 2015, North America's Midcontinent Rift: when rift met LIP: Geosphere, v. 11, no. 5, p. 1607-1616.

Stein, S., 2011, Learning from failure: The SPREE Mid-Continent Rift experiment: GSA Today, v. 21, p. 5-7.

Stein, S., Stein, C. A., Elling, R., Kley, J., Keller, G. R., Wysession, M., Rooney, T., Frederiksen, A., and Moucha, R., 2018, Insights from North America's failed Midcontinent Rift into the evolution of continental rifts and passive continental margins: Tectonophysics, v. 744, p. 403-421. 
Survey, G., Cannon, W. F., and Nicholson, S. W., 2001, Geologic map of the Keweenaw Peninsula and adjacent area, Michigan, The Survey.

Swanson-Hysell, N. L., Ramezani, J., Fairchild, L. M., and Rose, I. R., 2019, Failed rifting and fast drifting: Midcontinent rift development, Laurentia's rapid motion and the driver of Grenvillian orogenesis: Bulletin, v. 131, no. 5-6, p. 913-940.

Tyrrell, C., 2019, Keweenaw Fault Geometry and Slip Kinematics - Bête Gris Bay, Keweenaw Peninsula, Michigan

White, W. S., 1952, Imbrication and initial dip in a Keweenawan conglomerate bed [Michigan]: Journal of Sedimentary Research, v. 22, no. 4, p. 189-199.

Wolff, R. G., and Huber, N. K., 1973, The Copper Harbor Conglomerate (middle Keweenawan) on Isle Royale, Michigan, and its regional implications, 2330-7102.

Woodruff, L. G., Schulz, K. J., Nicholson, S. W., and Dicken, C. L., 2020, Mineral deposits of the Mesoproterozoic Midcontinent Rift system in the Lake Superior region - A space and time classification: Ore Geology Reviews, v. 126, p. 103716.

Wright, J. C., and Cornwall, H. R., 1954, Bruneau Creek, Michigan bedrock geology. 